Faculdade de Ciências Econômicas UFRGS

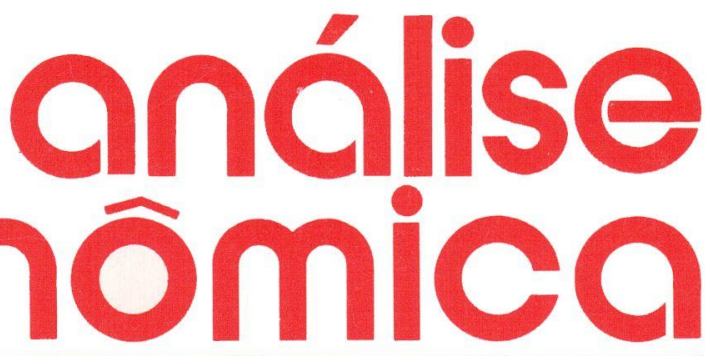

- PROgRAMA dE ESTABILIZAÇÃo DO GOVERNO COLLOR: CENTO E DEZ DIAS DEPOIS

Yeda Rorato Crusius

- SEGURO-DESEMPREGO E SUA INTEGRAÇÃO COM O SISTEMA NACIONAL DE EMPREGO José Paulo Zeetano Chahad

- RENDIMENTOS DECRESCENTES E PREÇO DO CAPITAL

Paolo Sylos Labini

- MARK-UP E DESTRUIÇÃO CRIADORA

Flávio Vasconcellos Comim

- TEORIA MONETÁRIA DE KEYNES Fernando Ferrari Filho

- ESTADO E PEQUENA PRODUÇÃO José Juliano de Carvalho Filho Ana Maria Castelo

- RACIONALIZAÇÃo DA PRODUÇÃo E ENSINO PROFISSIONAL (RS: 1889-1930) Sanara Jatahy Pesavento

- CONTRIBUICÕ̃ES À TEORIA DA LOCALIZAÇÃO INDUSTRIAL

Ruy Aguiar da Silva Leme

- POlaRizaÇÃo E deśolarizaÇÃo INDUSTRIAL NO BRASIL E NO RIO GRANDE DO SUL

Nali de Jesus de Souza
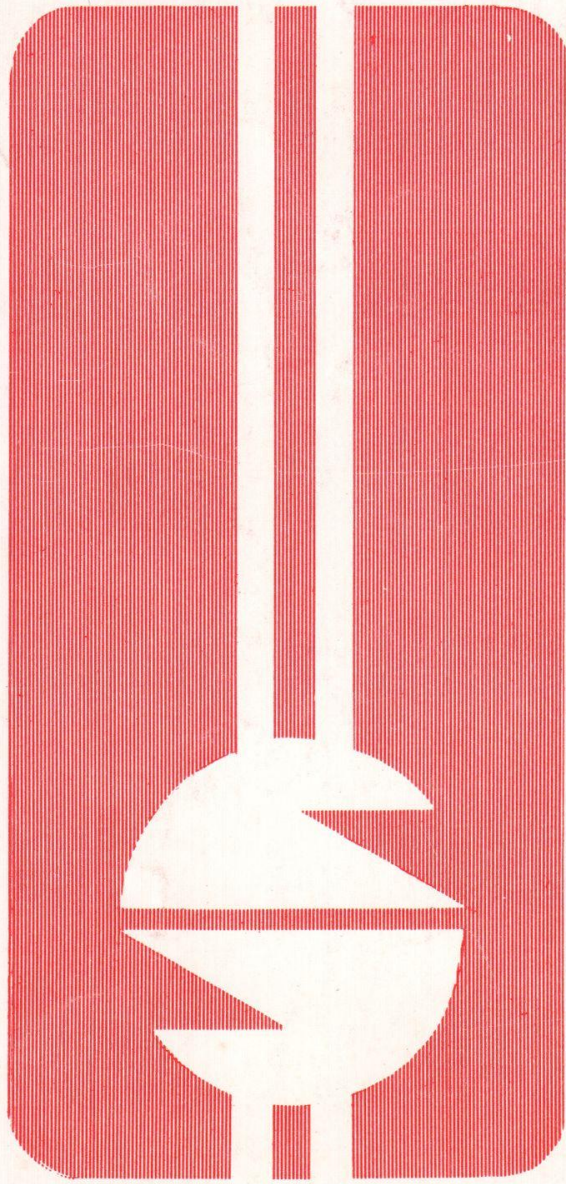
UNIVERSIDADE FEDERAL DO RIO GRANDE DO SUL

Reitor. Prof. Tuiskon Dick

FACULDADE DE CIÊNCIAS ECONÔMICAS

Diretor. Prof. Walter Meucci Nique

CENTRO DE ESTUDOS E PESQUISAS ECONÔMICAS

Diretor: Reinaldo Ignacio Adams

DEPARTAMENTO DE CIÉNCIAS ECONÔMICAS

Chefe: Prof. Pedro Cezar Dutra Fonseca

CURSO DE PÓS-GRADUAÇÃO EM ECONOMIA

Coordenador. Prof. Nali de Jesus de Souza

CURSO DE PÓS-GRADUAÇĀO EM ECONOMIA RURAL

Coordenador. Prof. Atos Freitas Grawunder

CONSELHO EDITORIAL: Achyles Barcelos da Costa, Aray Miguel Feldens, Atos Freitas Grawunder, Carlos Augusto Crusius, Ernani Hickmann, João Rogério Sanson, Juvir Luiz Mattuella, Maria Imilda da Costa e Silva, Nali de Jesus de Souza, Nuno Renan Lopes de Figueiredo Pinto, Otília Beatriz Kroeff Carrion, Otto Guilherme Konzen, Paulo Alexandre Spohr, Pedro Cezar Dutra Fonseca, Reinaldo Ignacio Adams, Roberto Camps Moraes, Valter José Stülp, Yeda Rorato Crusius, David Garlow (Wharton Econometrics Forecasts Association, E.U.A.), Edgar Augusto Lanzer (UFSC), Eleutério F.S. Prado (USP), Fernando Holanda Barbosa (FGV/RJ), Gustavo Franco (PUC/RJ), Joaquim Pinto de Andrade (UnB), Juan H. Moldau (USP), Werner Baer (Univ. de Illinois, E.U.A.).

COMISSÃO EDITORIAL: Atos Freitas Grawunder, Pedro Cezar Dutra Fonseca, Reinaldo Ignacio Adams e Roberto Camps Moraes.

EDITOR: Nali de Jesus de Souza.

SECRETARIA: Maria Ivone de Mello (normalização), Vanete Ricacheski (revisão de textos), Zélide Bregalda (Secretária).

FUNDADOR: Prot. Antônio Carlos Santos Rosa.

Os materiais publicados na revista Análise Econômica são de exclusiva responsabilidade dos autores. É permitida a reprodução total ou parcial dos trabalhos, desde que seja citada a fonte.

Aceita-se permuta com revistas congêneres. Aceitam-se, também, livros para elaboração de resenhas ou recensões.

Toda correspondência, material para publicação, assinaturas e permutas devem ser cirigidos ao seguinte destinatário:

PROF. NALI DE JESUS DE SOUZA

Revista Análise Econômica

Av. João Pessoa, 52

90.040 - PORTO ALEGRE (RS), BRASIL

Telefone: 25-58-44 ramal 33 


\section{O PROGRAMA DE ESTABILIZACÃO DO GOVERNO COLLOR: CENTO E DEZ DIAS DEPOIS*}

Yeda Rorato Crusius ${ }^{\star \star}$

\section{INTRODUÇÃO}

O choque causado à economia brasileira pelo programa de estabilização denominado "Plano Brasil Novo", divulgado um dia após a posse do governo Collor de Melo em 15 de março de 1990, foi, sem dúvida, o mais forte de todos os aplicados nos anos 80 na tentativa de debelar o processo inflacionário brasileiro. O programa, assim corno.os anteriores, teve por base o diagnóstico do caráter predominante expectacional da inflação, aliado ao esgotamento da capacidade do governo em utilizar ativamente tanto os instrumentos de uma política convencional de estabilização quanto os de direcionamento do desenvolvimento nacional. $A$ abrangência do programa, assim como a inovação quanto à reforma monetária perpetráda, somadas à inexistência de um documento técnico que servisse de base para o melhor entendimento e avaliação global do programa e de suas metas, jogaram a economia e a sociedade num periodo de profunda desorganização e perplexidade. O Governo, avocando a si a total responsabilidade quanto ao programa, afirmou que, em cem dias, seus resultados teriam sido completados, com a queda definitiva da inflação a uma taxa inferior a $10 \%$ ao mês, quando então seria iniciada a nova fase: a da volta ao crescimento econômico.

\footnotetext{
* Trabalho desenvolvido através dos arquivos armazenados pelo Grupo de Estudos de Conjuntura Económica, da Faculdade de Ciências Económicas da UFRGS. Os bolsistas do CNPq, e da FAPERGS ligados ao Grupo, Denise Androvandi e Maristela Valério Kopp, e André Luis de Assis participaram ativamente na organização dos documentos e dados utilizados no artigo.

** Professora Titular do Departamento de Ciências Econômicas e do Curso de Pósagraduação em Economia da Universidade Federal do Rio Grande do Sul.
}

\begin{tabular}{|l|l|l|l|l|}
\hline ANÁLISE ECONÔMICA & ANO 8 & No13 & MARÇO/90 & p.3-41. \\
\hline
\end{tabular}


Este artigo objetiva, passados 110 dias do seu lançamento, avaliar o programa de estabilização como ele se apresentou à sociedade, e os seus impactos sobre a conjuntura. Para tanto, na parte II são apresentados os principais indicadores da conjuntura pré-plano, que evidenciam os resultados da política econômica até então, através da tendência à aceleração da taxa de inflação. Na parte III são discriminados os objetivos e os instrumentos utilizados pelo programa no conjunto de reformas apresentadas através do documento publicado nos jornais do dia 17 de março, e da sua implementação através da farta edição de medidas provisórias, resoluçöes, portarias, etc., nos 110 dias que seguiram. Os principais resultados do plano são apresentados na parte IV, assim como as perspectivas trazidas pela divulgação da Nova Política Industrial e de Comércio Exterior, em junho, deste ano.

\section{ESTADO DA CONJUNTURA PRÉ-PLANO "BRASIL NOVO"}

O período mais relevante para a análise do estado da conjuntura pré-plano refere-se ao do final do Governo Sarney, durante o qual foram aplicados o Plano Cruzado (fevereiro de 1986), o Plano Bresser (junho de 1987) e o Plano Verão (janeiro de 1989). Partindo do diagnóstico do caráter fortemente inercial da inflação e financeiro do déficit público, os três choques contaram com ingredientes similares de política econômica, aplicados em doses distintas conforme o plano: tentativa de ajuste fiscal e de desindexação da economia, política monetária e polítjca cambial passivas e reforma monetária. A cada nova tentativa de desindexação, menor se tornava o periodo de intervalo entre o choque e a volta, com ímpeto ampliado, da inflação (ver Gráfico 1). Elementos não antecipados pelos agentes econômicos rarefaziam-se, diminuindo a eficácia de política de estabilizaçāo do tipo "choque".

Os fatos mais marcantes que antecederam a decretação do Plano "Brasil Novo" são buscados nos resultados do Plano Verão, já em vigor a nova Constituição de outubro de 1988 (GECE, 1989). Fracassadas as tentativas de romper com a inércia da inflação através de um pacto de preços, o plano foi apresentado como a única opçáo possivel de evitar um processo aberto de hiperinflação no ano das eleições presidenciais. A exemplo de choques anteriores, foi mudada a moeda (cruzado para cruzado novo, ao par), feita uma mididesvalorização do câmbio, divulgado um congelamento de preços e mudada a base do indice oficial de in- 
flação (IPC/IBGE). Essa mudança resultou na taxa de $70,28 \%$ para janeiro, correspondente a 45 dias de aferição de preços pelo IBGE, cuja divulgação gerou expectativas dos agentes econômicos a respeito de um novo teto para a inflação e sua conseqüente incorporação aos contratos existentes; até o final da gestão de Mailson da Nóbrega, essa taxa já havia sido incorporada, inclusive aos salários, alterando os patamares da inércia para os reajustes de salários e preços, um dos elementos que explicam a volta da taxa de inflação a $72,78 \%$ em fevereiro de 1990.

No entanto, distintamente dos outros planos, foi extinto o indexador oficial (OTN - Obrigação do Tesouro Nacional) substituido apenas em abril pelo BTN - Bonus do Tesouro Nacional (MP - Medida Provisória 48, de 19/04/89), com valores retroativos ao início do plano. Arbitrando uma variação de $16 \%$ para a variação de fevereiro, a série contínua do indexador oficial pôde ser refeita, sendo atualizada mensalmente pelo IPC/iBGE. A reindexação de ativos é feita em junho, com a criação como referencial de indexação para tributos e contribuições de competência da União o BTNf, reajustado diariamente de acordo com a expectativa da inflação apontada pelo Governo e mensalmente conforme a variação do valor do BTN (MP 68, de 14/06/89), e criado o BTNc (BTN cambial), reajustado de acordo com a variação do dólar. Com a reaceleração da inflação, tanto o BTN quanto o BTNf voltaram a ser os principais indexadores de contratos na economia.

A política de rendas do Plano Verão extinguiu a URP, que regulava os reajustes dos salários, substituída apenas em junho por nova regra salarial (MP 70) e, finalmente, promulgada nova lei reindexando salários pelo Congresso Nacional em julho. Como saída do congelamento, em abril (MP 48), foram tentados reajustes trimestrais de preços não superiores ao IPC acumulado no periodo. Em outubro, como resultado de acerto com os empresários, o governo anunciou nova regra de reajustes automáticos em $90 \%$ da inflação do mês anterior, e superiores a essa taxa quando aprovado por Câmaras Setoriais. O mercado se encarregou de sepultar essas regras para preços e salários.

No campo fiscal, o Governo anunciou mais um pacote, com proposta de privatizar 17 das 64 empresas estatais, reduzir alíquotas de importação e extinguir 120.000 vagas no funcionalismo. Terminado o periodo de Governo, o saldo foi urn aumento significante no número de funcionários admitidos e nenhuma privatização.

Para remunerar o sistema financeiro de modo e evitar a fuga a ati- 
vos de especulação, como o dólar no mercado paralelo, pela incerteza a respeito da remuneração à moeda indexada, o Governo arbitrou taxas para o "overnight", aplicáveis à caderneta de poupança, que resultaram em ganhos nominais (e reais, por certo periodo) extraordinários. As informações contidas na Tabela 1 e nos Gráficos 2 e 3 confirmam os resultados dessa opção. A substancial acumulação de ganhos puramente especulativos através da política de sustentação de juros diários elevados, aliada ao retorno à indexação generalizada e ampliada (pelo BTNf), resultaram na manutenção de um nivel elevado de consumo, na virtual paralisação dos investimentos não relacionados com esses setores de consumo, e na crescente expectativa de que a dívida pública, fundada nessas bases, a partir de algum momento deixaria de ser honrada. A inovação realizada pelo Plano Verão, da extinção mesmo que temporária da moeda indexada (OTN) justificava essa expectativa.

As incertezas quanto à direção da inovação no campo da política de estabilização prometida pelo presidente eleito nos meses que antecederam à sua posse, aceleraram as expectativas inflacionárias, a remarcação preventiva de preços, a saída de capitais externos do país. A dimensão desses movimentos pode ser percebida pela análise dos principais indicadores de atividade econômica descritos nas Tabelas 3, 4, 5 e 6.

\section{O PLANO "BRASIL NOVO"}

Anunciado o plano de estabilização em 16 de março, foi extraordinário o choque causado pela inovação quanto à reforma monetária, com a liberação limitada de cruzeiros e o congelamento por 18 meses dos saldos das aplicações em cruzados novos. A falta de um documento técnico que embasasse as necessárias análises e que justificasse essa opção marcou a forma de gestão que se confirmaria ao longo dos 110 dias que se seguiram à divulgação do plano. O plano correspondeu a uma bomba armada que submeteu a sociedade à sua orientação, que é a de mudança de regime de política económica (Crusius, 1990). O Plano Collor correspondeu a uma opção de reforma monetária do tipo II, próxima à aplicada na Bélgica, de acordo com a tipificação oferecida por Gurley (1990) em artigo, desconhecido pela quase totalidade dos pesquisadores nacionais, no qual a concepção e conseqüência da aplicação de 24 reformas monetárias na Europa entre 1944 e 1952 estão farta e minuciosamente analisadas pelo autor (Moraes in Gurley, 1990). 


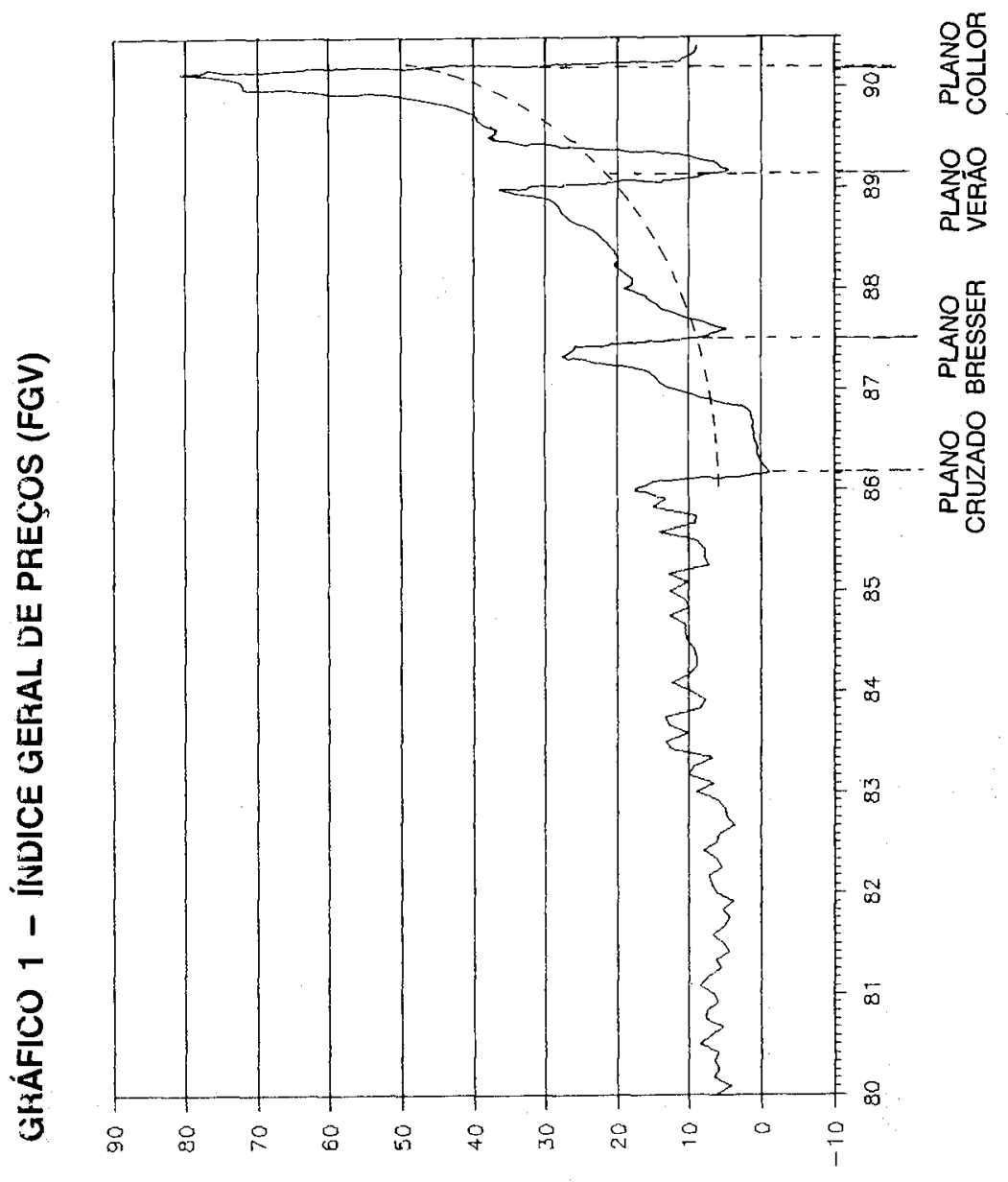




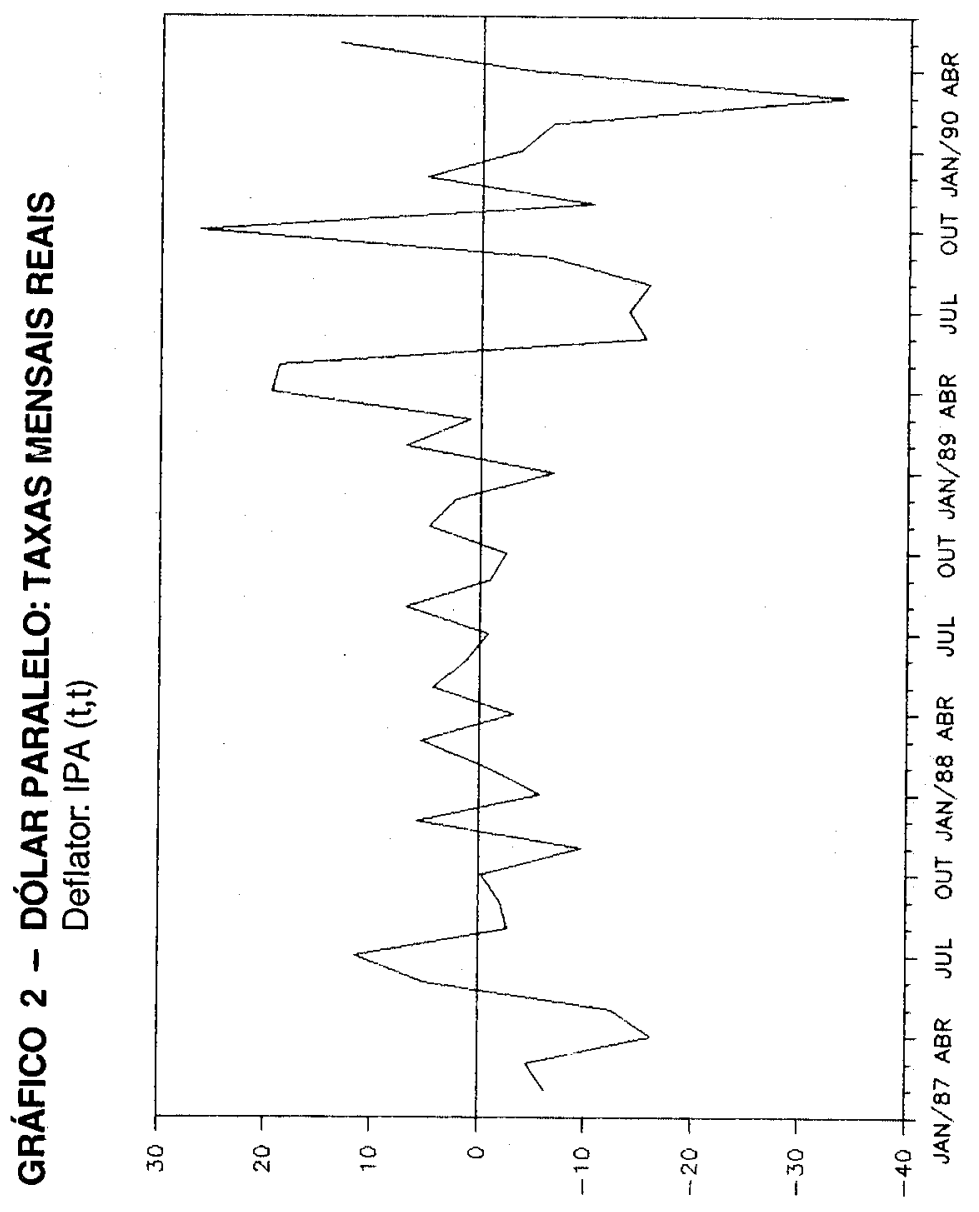




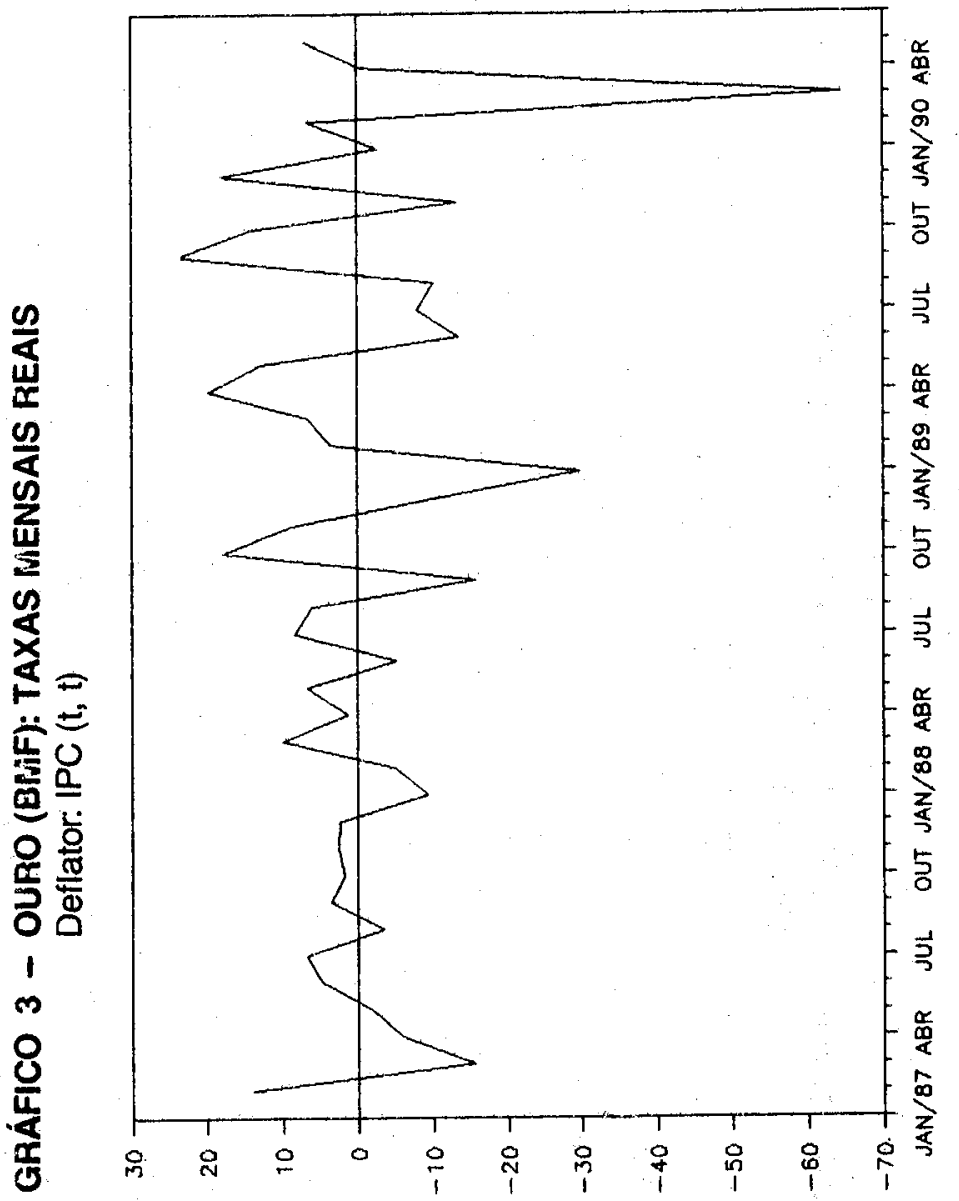




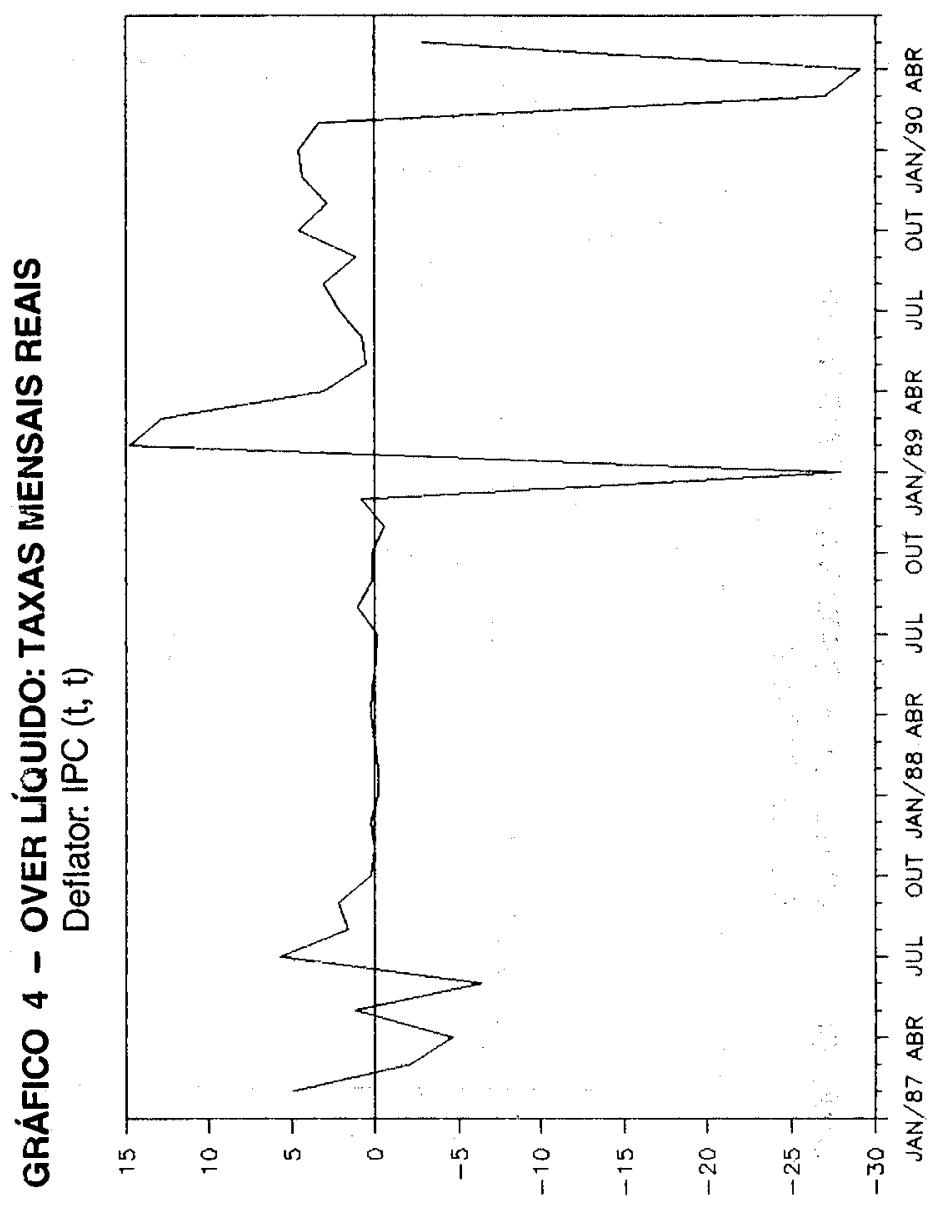




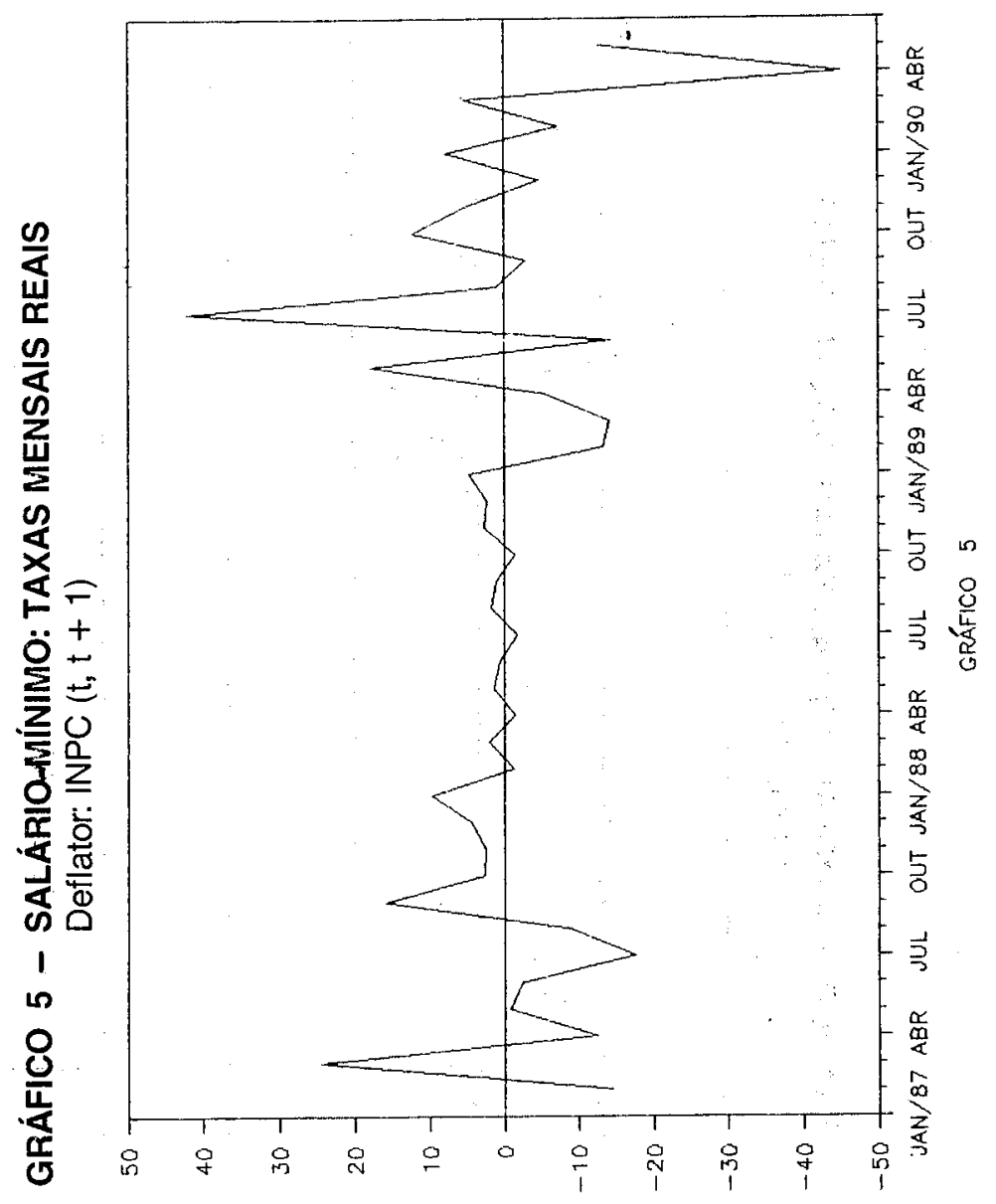




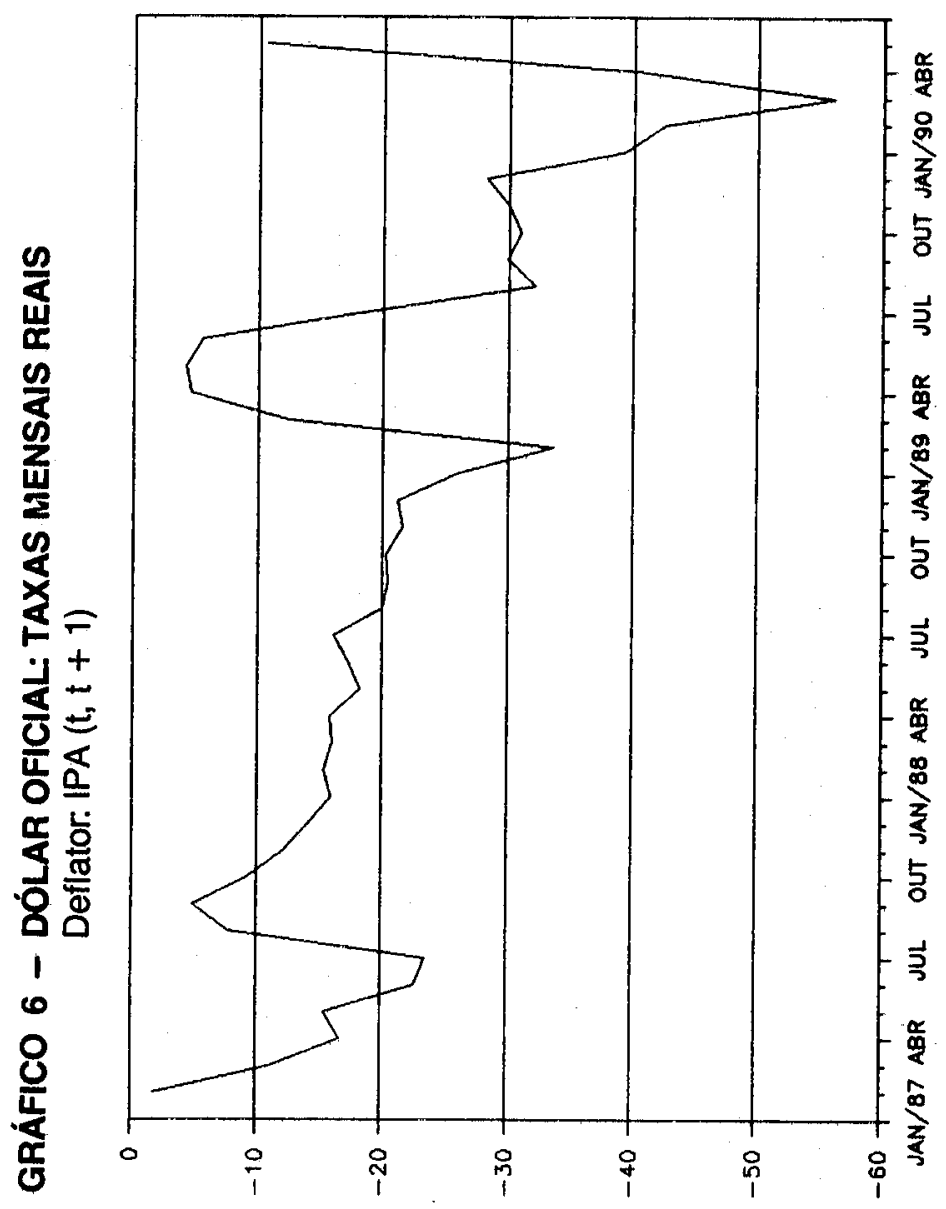




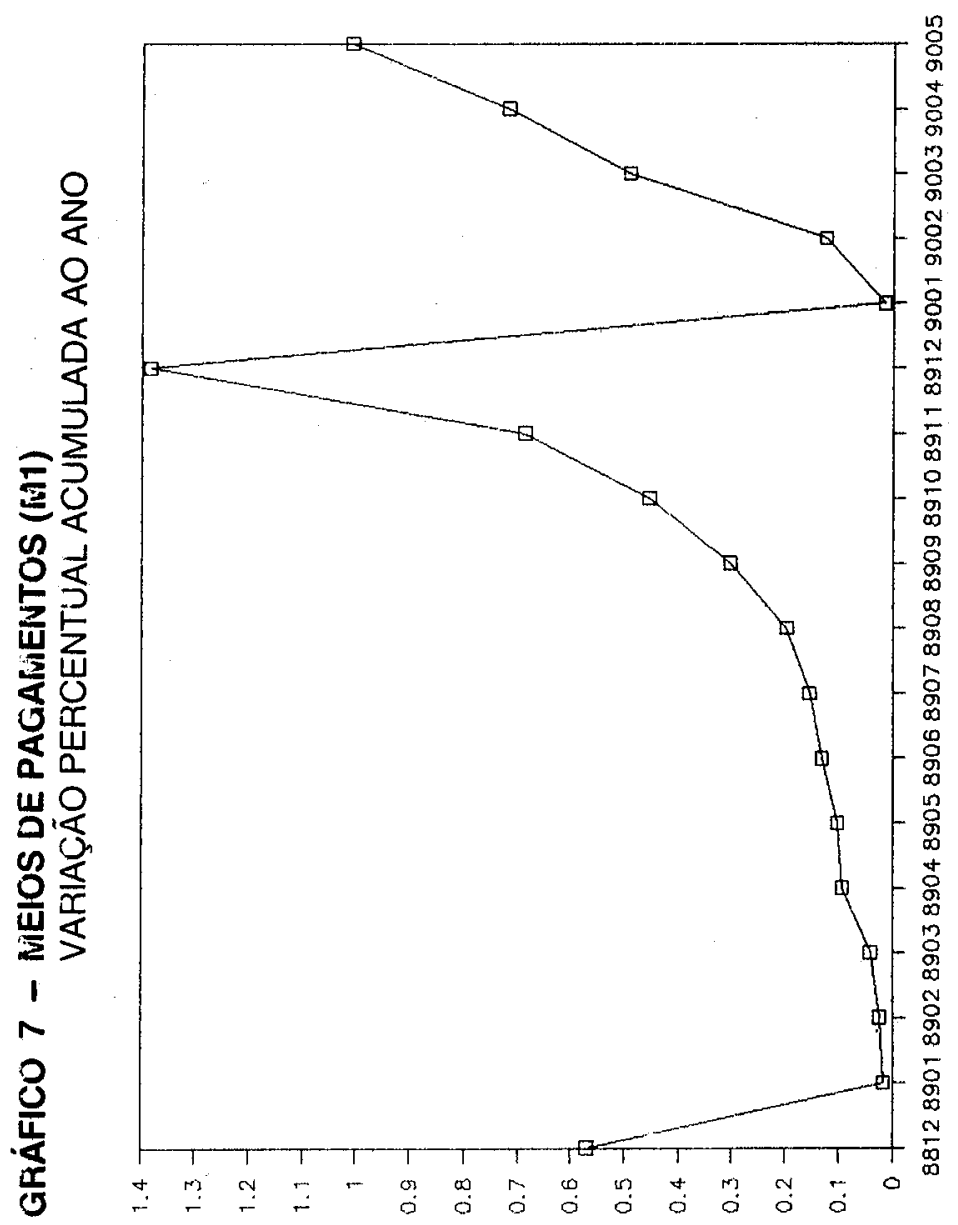


Muitos equívocos de gestão do plano e desgastes desnecessários para a sociedade poderiam ter sido evitados se problemas práticos decorrentes de uma reforma desse tipo fossem donhecidos do Governo, e se a base técnica do plano tivesse sido adequadamente divulgada.

Segundo o discurso oficial, o programa de estabilização objetiva recuperar a capacidade do Governo de fazer politica ativa, eliminando a inflação e transformando o déficit público de $8 \%$ do PIB em um superávit de $2 \%$, ainda em 1990, através de um conjunto consistente de reformas (administrativa, patrimonial, monetária, fiscal, de rendas e cambial). Os instrumentos legais utilizados para realizar essas reformas foram as Medidas Provisórias (MP), os Decretos (D) e os Projetos de Lei (PL). O conjunto resultante está descrito no Anexo, que resume cada medida e seu andamento até junho de 1990.

A medida de maior impacto instantâneo foi a reforma monetária (RM), através da qual foi substituído o cruzado novo pelo cruzeiro ao par para valores limitados conforme o tipo de aplicação ("over", poupança, fundo de curto prazo, etc.), com a possibilidade de troca com deságio (fora do par) pelos anunciados leilões de cruzados novos retidos, e a devolução em cruzeiros após 18 meses, dos cruzados novos retidos corrigidos como a caderneta de poupança. Todos os ativos foram atingidos, exceto a moeda líquida sacada antes do plano e fora do sistema financeiro. A ausência de medida que atingisse também essa parcela da moeda (como a troca da moeda física, ou a exigência de um carimbo, a exemplo do que será novamento feito na integração das Alemanhas de 1990), introduziu um inadmissivel viés de não-neutralidade à reforma. A eliminação da moeda "má", a moeda "puramente especulativa", devolveria ao governo a capacidade de fazer política ativa no campo monetário. Segundo estimativas oficiais, $80 \%$ da liquidez existente na economia em inicio de março ficou retida até que diversas formas de acesso aos cruzados novos foram sendo gradualmente abertas (pagamento de impostos, folhas de salários, etc.). O comprometimento de um rígido estabelecimento de metas, pelo futuro orçamento monetário, completou esse campo de reforma. Após três meses, estima-se que apenas poupadores e bancos tenham ficado com saldo retidos em cruzados novos. A remonetização foi exageradamente acelerada exigindo a redução drástica da liquidez a partir de maia, com custos sociais desnecessários sobre o nivel de emprego e de atividade na economia (ver Tabela 6).

Para reverter o déficit público, foram anunciadas as metas (1) da reforma administrativa (RA), contemplando demissão de 360 mil fun- 
cionários públicos, fechamento de ministérios, autarquias e empresas públicas, e reestruturação das despesas do Estado, com o objetivo de economizar $0,5 \%$ do PIB; (2) da reforma patrimonial (RP), através da privatização de empresas públicas que resultariam na arrecadação de 1,5\% do PIB (US\$ 7 bilhões), e colocação compulsória dos Certificados de Privatização (CP), calculados como função do patrimônio das empresas do sistema financeiro nacional, no valor estimado de $2 \%$ do PIB, a serem destinados somente ao resgate de títulos da divida pública; (3) da reforma fiscal (RF), com proposta de criação de imposto sobre patrimônio a partir de 1991, redução dos prazos de recolhimento de impostos (agora calculados em BTNf), elevação de aliquotas (IOF, com prevísão de arrecadação apenas neste item de 3\% do PIB) através da qual todos os agentes econômicos passariam a pagar impostos (ex.: renda agrícola e todas as aplicações financeiras, inclusive em bolsas de valores) e registrar transações (fim do anonimato): $A \cdot R F$, pelo lado das despesas, eliminou todos os subsidios e incentivos não constitucionais. Com essas medidas, a economia seria de mais 3\% do PIB. Esse conjunto de reformas, mais o impedimento de que o Banco Central financie gastos do Tesouro Nacional, teria alterado o regime de política fiscal, e feito desaparecer o déficit estrutural do setor público.

A nova Política de Rendas afirmou a regra da livre fixação para todos os preços e salários dentro de um prazo que a própria resposta da economia ao choque determinaria. Precedido do realinhamento de preços e tarifas ${ }^{1}$, foi decretado um congelamento temporário. A regra de indexação salarial caiu, tendo sido arbitrada para março a taxa de inflação de fevereiro $(72,78 \%$ ) como reajuste para todos os salários, e a de $41,28 \%$ para o BTN. (Ao final do mês, foi registrada a taxa de variação de $84,32 \%$ para o IPC de março). Para o período de transição até a total livre negociação, exigida como regra de reajustes, o plano estabelecia uma agènda na qual a inflação, pré-fixada no dia 15 de cada mês, daria o piso de reajuste do salário (mínimo, sendo todos os demais livremente negociados) daquele mesmo mês, enquanto o teto para o reajuste dos preços seria dado no primeiro dia do mês seguinte. Com essa regra, para o Governo, os salários teriam ganho real, pois subiriam sempre antes do que os preços. Ademais, se a inflação pré-fixada fosse menor do que a inflação real a reposição da diferença teria que ser negociada com os

10 processo ativo de realinhamento de preços e tarifas públicas, assim como várias medidas relativas à despesa com funcionalismo e à gestão monetária, foi iniciado nos últimos meses da gestão Mailson da Nobrega, recaindo seus efeitos nas taxas de inflação anteriores ao Plano "Brasil Novo". 
patrōes, sendo que a "inflação real" seria medida por um novo indice, no sistema "ponta a ponta", que até o final dos 110 primeiros dias do plano ainda não havia sido estruturado. Em realidade, a préfixação do Governo para a inflação foi de zero \%, resultando, na prática, no congelamento do salário-mínimo até junho, enquanto a inflação indicada por quaisquer dos índices disponiveis foi positiva já a partir de abril. Os preços foram totalmente liberados, com exceções para produtos da cesta básica. A confusa gestão das autoridades econômicas nesse campo resultou em que o único "farol" disponivel é que a reindexação dos salários será de todos os modos evitada pelo Governo.

Por último, a reforma cambial, apesar de poder estar contida na nova política de rendas, merece destaque. Em primeiro lugar, porque o Governo, desde a campanha, afirmou que primeiro faria o ajuste interno, criando condições e mostrando resultados que determinariam o ajuste externo de mesmo caráter: inovador e definitivo. Em segundo lugar, porque, com essa reforma, se completaria a "consistência" do programa. $O$ Governo anunciou a livre formação da taxa de câmbio, a ser operado por agentes autorizados, originando as taxas de câmbio flutuante (ou comercial), a de turismo, e a do mercado paralelo. $O$ anúncio dessa medida em março foi feito com a antecipação de outras medidas na área de comércio exterior e câmbio: em breve a redução das barreiras alfandegárias e o estímulo à participação do capital estrangeiro, dentre outras que apontariam para a liberalização da economia brasileira. A mudança de regime nesta área, assim como na da política de rendas, se completaria em pouco tempo: em cem dias o próprio Governo e o mercado teriam se adaptado a essa nova orientação.

\section{OS IINIPACTOS DO PROGRAlUIA DE ESTABILIZAÇÃO APÓS 110 DIAS}

O exame do Anexo mostra o difícil processso de implementação do plano, que prescindiu da obediência a variadas regras legais existentes (julgamentos de inconstitucionalidade, retirada de medidas claramente ilegais, reedição de medidas provisórias, etc.) A firme determinação do Governo em fazer valer a direção dada ao processo de estabilização a qualquer custo buscaria afirmar, aos agentes 'econômicos, a recuperação da capacidade dos instrumentos convencionais de política econômica dentro do quadro de força permitido ao próprio Governo pela atual 
estrutura organizacional do País. Porém, além da explicitação da vontade, existem condições técnicas e políticas que devem ser respeitadas para que o plano leve a uma acomodação eficiente da economia às novas regras.

A aprovação pelo Congresso Nacional de praticamente todo 0 conjunto de medidas editadas pelo Governo garantiu sua aplicabilidade imediatamente. Porém, além do Congresso, todos os agentes econômicos e o próprio Governo passaram a atuar em regime de dedicação exclusiva aos requerimentos de ação diária que o plano demandou. Como decorrência de qualquer choque que rompa as regras de indexação formais, a recontratação a todos os niveis teve seu processo iniciado imediatamente após o plano; a falta de regras, e os avanços e retrocessos contínuos de gestão pelo próprio Governo, criaram um quadro de desorganização na economia. Os resultados macroeconômicos relevantes, indicados nas Tabelas 2 e 6 , apontam para um custo social elevado e, ainda para a indefinição quanto à trajetória da inflação.

$O$ valor dos ativos financeiros caiu drasticamente, como em todos os processos de redução instantânea da inflação. A taxa de inflação, mesmo após a ampla liberação de preços, chega próximo aos $10 \%$ mensais objetivada pelo Governo, em parte devido à recessão provocada e ao virtual congelamento no preço de custos básicos (salários de amplas categorias de trabalhadores, tarifas públicas) e, em parte, à resistência quanto à reindexação da economia. A redução do nivel de atividade industrial $(-10,9 \%$ em maio, e $-6,3 \%$ de janeiro a maio de 1990 , segundo cálculos da FIESP), a redução dos salários médios reais (-24,9\% em maio e $-6,2 \%$ acumulados em 1990, pela mesma fonte), e do índice de produção industrial até maio (-5,3\% jan-maio/90, comparado com o mesmo período de 1989, de acordo com o IBGE) mostram que trazer a taxa de inflação de $80 \%$ para $10 \%$ ao mês não se faz através de um processo indolor - apesar das declarações oficiais nos primeiros meses deste governo.

O superávit de caixa registrado pelo Tesouro garante um equilibrio de contas para o ano, enquanto a intensidade da recessão não romper o equilíbrio entre a recessão como instrumento de compressão de salários e preços e a meta de superávit. A reforma fiscal, até os 110 dias do plano, ainda se encontra incompleta, não tendo se iniciado a colocação dos CPs nem sido obtida a meta de redução dos gastos correntes. A manutenção das metas do orçamento monetário anunciadas restringe a liquidez em cruzeiros e a preservação dos niveis de reservas internacionais. 
Os indicadores financeiros, com a redução do ágio entre o dólar comercial e o do mercado paralelo (na Tabela 4, indicado pela média aritmética mensal das cotações diárias) mostram que a economia se adapta à mudança de regime de política econômica. Nesse período, a equipe econômica chancela modificações de gestão fundamentais, sugeridas no decorrer desse processo de adaptação (ex.: análise da política monetária em Pastore, 1990).

As condições iniciadas com as mudanças ditadas pela nova política industrial e de comércio exterior, desencadeadas em junho, encontram a economia em estado de recessão. Apresentada como "uma ruptura em relação ao passado protecionista", a politica vai buscar aumento da eficiência através da exposição da economia brasileira à concorrência, e coloca o governo não mais como motor do desenvolvimento através de sua própria demanda, e sim como coordenador do novo padrão de desenvolvimento baseado em capacitação tecnológica e equcação. Ou seja, ações de resultados no lonyo prazo. Medidas de alcance no curto prazo são a redução imediata de restrições no campo do comércio exterior, inclusive as referentes a tarifas alfandegárias. Outras ações no campo da integração econômica com países latinos e no campo da renegociação da dívida externa confirmam a direção de liberação da economia e a apontam para a forma integracionista de inserção no novo ciclo internacional - mas para concretizá-las requer-se investimento. Nesta etapa, além de juízo, é necessário sorte. O programa de estabilização tem que ser completado para que o financiamento da atividade econômica tenha se alterado em seu padrão. As incertezas, quanto a já se estar no caminho desse novo padrão, ainda são gigantescas. A sincronicidade entre os movimentos da economia mundial e da nacional depende de elementos objetivos, tais como eliminação das pressões inflacionárias básicas e um retorno em curto período de tempo ao crescimento econômico. Portanto, condições para o retorno dos investimentos a serem financiados agora sem ser pelo processo inflacionário. Essas são as condições básicas para a eficiência a médio prazo do programa o qual atingiu suas metas de curtíssimo prazo. O desmonte das estruturas anteriores ao plano, sem uma necessária reconstrução através de investimento pesado (com a questão fundamental de quem o realizará, e quem o financiará) em energia, educação básica, ciência e tecnologia, saúde democracia econômica, apenas resultará na continuidade da insuportavelmente ampliada concentração de renda e poder que marca o caráter da história econômica recente do País. Tudo está por ser feito, sob o novo regime de política econômica. 


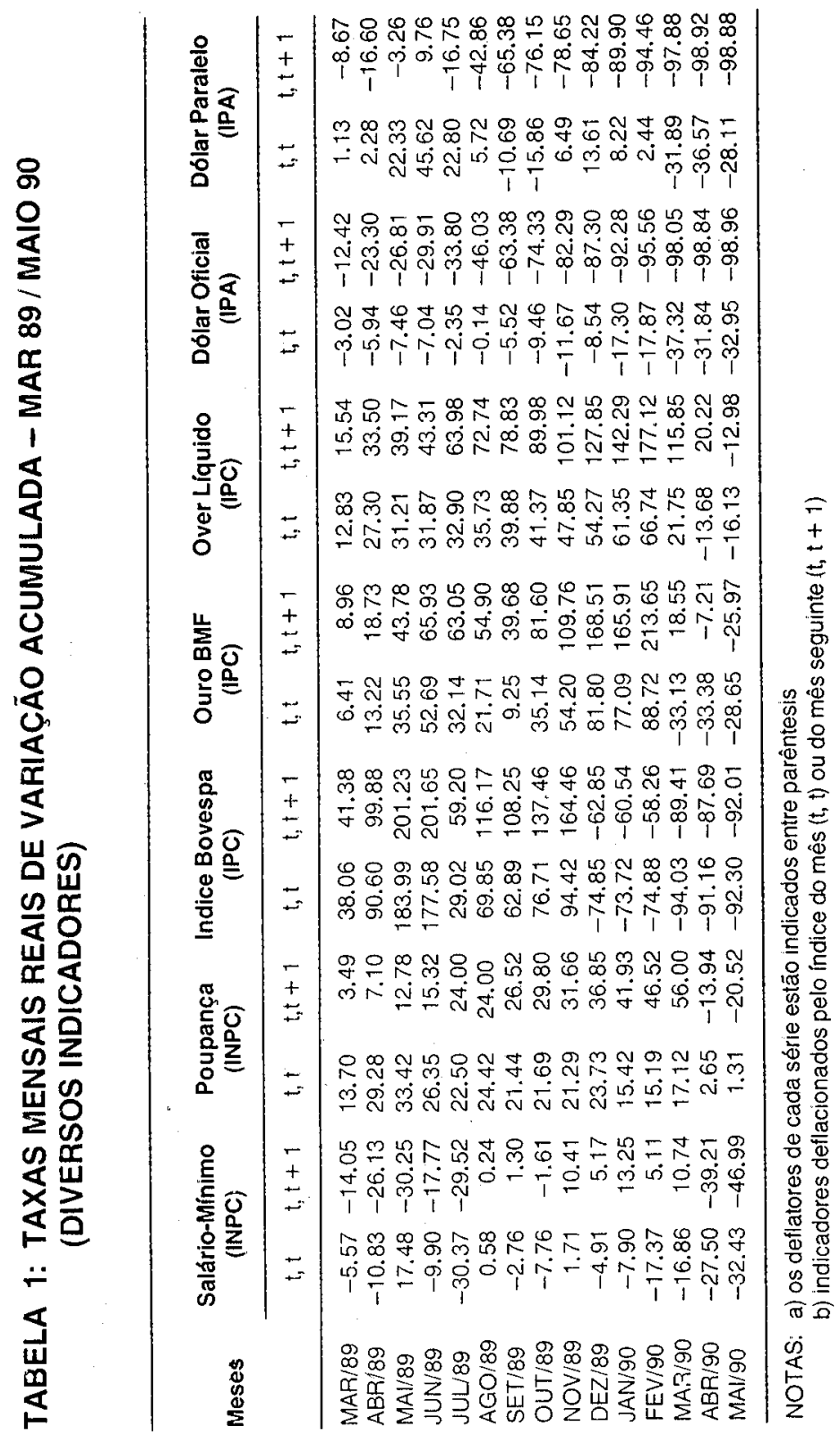




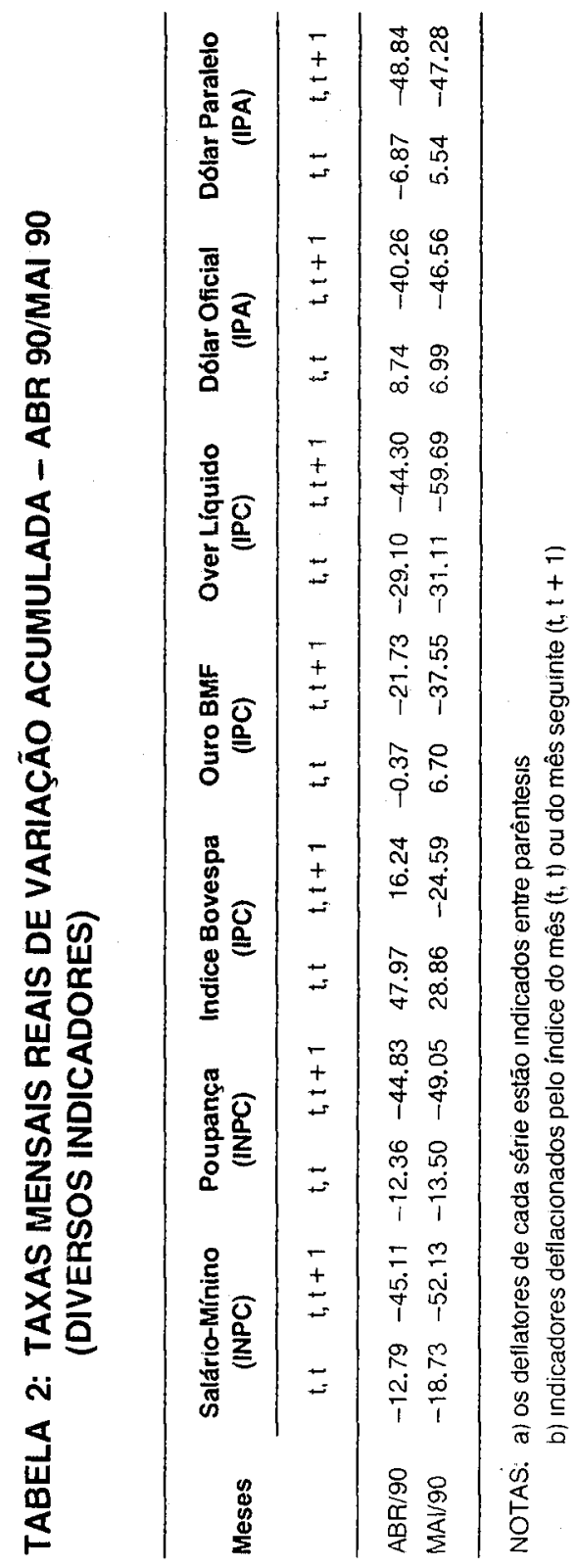


TABELA 3: INDICADORES ECONÔMICOS SELECIONADOS JAN 87 / ABR 90

\begin{tabular}{|c|c|c|c|c|c|c|c|}
\hline \multirow{2}{*}{ Ano/Més } & \multicolumn{5}{|c|}{ Desemprego Aberto (\%) } & \multicolumn{2}{|c|}{ Produção Industrlal } \\
\hline & $\begin{array}{l}\text { Indústria } \\
\text { Transf. }\end{array}$ & $\begin{array}{c}\text { Constr. } \\
\text { Civil }\end{array}$ & Comércio & Serviços & $\begin{array}{c}\text { Outras } \\
\text { Atividades }\end{array}$ & $\begin{array}{c}\text { Taxa } \\
\text { Mensal }\end{array}$ & $\begin{array}{l}\text { Acumulado } \\
\text { Doze Meses }\end{array}$ \\
\hline 8701 & 3.76 & 3.25 & 3.33 & 2.36 & 1.19 & 5.41 & 10.78 \\
\hline 8702 & 3.75 & 3.02 & 3.86 & 2.65 & 1.21 & 1.60 & 10.74 \\
\hline 8703 & 3.61 & 3.23 & 3.96 & 2.43 & 1.62 & -2.82 & 11.60 \\
\hline 8704 & 4.11 & 3.23 & 4.11 & 2.46 & 1.41 & 2.96 & 10.72 \\
\hline 8705 & 4.93 & 4.29 & 4.49 & 2.83 & 1.83 & -5.00 & 10.25 \\
\hline 8706 & 5.69 & 5.87 & 4.47 & 3.25 & 1.87 & -2.53 & 9.26 \\
\hline 8707 & 6.39 & 5.18 & 4.55 & 3.04 & 2.06 & -4.30 & 7.72 \\
\hline 8708 & 5.95 & 4.75 & 4.69 & 2.79 & 1.67 & -1.37 & 6.60 \\
\hline 8709 & 5.24 & 4.24 & 4.38 & 2.96 & 1.99 & 4.70 & 4.81 \\
\hline 8710 & 5.33 & 3.68 & 4.27 & 2.95 & 1.51 & -1.31 & 3.29 \\
\hline 8711 & 4.68 & 3.95 & 3.71 & 2.82 & 1.07 & 1.59 & 2.44 \\
\hline 8712 & 3.28 & 3.08 & 3.02 & 2.23 & 1.37 & -2.00 & 1.56 \\
\hline 8801 & 4.56 & 4.09 & 3.87 & 2.95 & 1.38 & -0.21 & 0.22 \\
\hline 8802 & 5.37 & 4.06 & 4.18 & 3.37 & 1.86 & 1.78 & -1.54 \\
\hline 8803 & 5.22 & 4.20 & 4.66 & 3.33 & 2.02 & 6.48 & -2.58 \\
\hline 8804 & 5.03 & 3.44 & 4.80 & 3.21 & 1.46 & -5.13 & -3.95 \\
\hline 8805 & 5.34 & 3.51 & 4.66 & 3.97 & 1.18 & -2.89 & -4.83 \\
\hline 8806 & 5.06 & 4.08 & 4.36 & 2.81 & 1.26 & 5.04 & -4.85 \\
\hline 8807 & 4.95 & 3.73 & 4.14 & 2.85 & 1.62 & -3.98 & -4.22 \\
\hline 8808 & 4.80 & 4.14 & 4.82 & 3.16 & 1.80 & 3.88 & -3.30 \\
\hline 8809 & 4.63 & 3.74 & 4.45 & 2.99 & 1.30 & -3.82 & -2.98 \\
\hline 8810 & 4.29 & 3.83 & 4.41 & 2.93 & 1.12 & -7.91 & -3.05 \\
\hline 8811 & 3.82 & 3.44 & 3.80 & 2.78 & 1.01 & 2.65 & -3.46 \\
\hline 8812 & 3.37 & 3.23 & 3.14 & 2.35 & 1.17 & 1.97 & -3.43 \\
\hline 8901 & 4.53 & 4.28 & 4.07 & 2.99 & 1.48 & 0.92 & -2.85 \\
\hline 8902 & 4.77 & 4.57 & 4.12 & 3.01 & 2.02 & -6.22 & -2.91 \\
\hline 8903 & 4.92 & 5.12 & 4.66 & 3.09 & 1.88 & 7.31 & -3.72 \\
\hline 8904 & 4.46 & 4.39 & 4.49 & 2.97 & 1.76 & 1.86 & -3.24 \\
\hline 8905 & 3.97 & 3.34 & 3.87 & 2.58 & 1.55 & 4.89 & -2.32 \\
\hline 8906 & 4.01 & 3.28 & 4.00 & 2.55 & 1.55 & 4.23 & -2.06 \\
\hline 8907 & 3.49 & 3.65 & 3.59 & 2.47 & 1.36 & -1.39 & -1.60 \\
\hline 8908 & 3.73 & 3.02 & 4.07 & 2.42 & 1.37 & 4.10 & -1.52 \\
\hline 8909 & 3.77 & 3.28 & 3.73 & 2.57 & 1.49 & -6.40 & -1.02 \\
\hline 8910 & 3.27 & 3.36 & 3.48 & 2.48 & 1.04 & -0.56 & 0.63 \\
\hline 8911 & 2.91 & 2.59 & 2.83 & 2.03 & 0.86 & 0.59 & 2.07 \\
\hline 8912 & 2.99 & 2.95 & 2.64 & 1.71 & 0.72 & -4.75 & 2.63 \\
\hline 9001 & 3.99 & 3.77 & 3.74 & 2.41 & 1.41 & -0.45 & 2.98 \\
\hline 9002 & 4.26 & 3.25 & 3.96 & 2.41 & 1.03 & -4.81 & 4.13 \\
\hline 9003 & 5.00 & 4.74 & 4.59 & 2.74 & 1.91 & 2.31 & 4.99 \\
\hline 9004 & 6.57 & 7.24 & 4.55 & 3.33 & 1.95 & & \\
\hline
\end{tabular}

FONTE: BANCO DE DADOS DO GECE - GRUPO DE ESTUDOS DE CONJUNTURA (FCE UFRGS) 


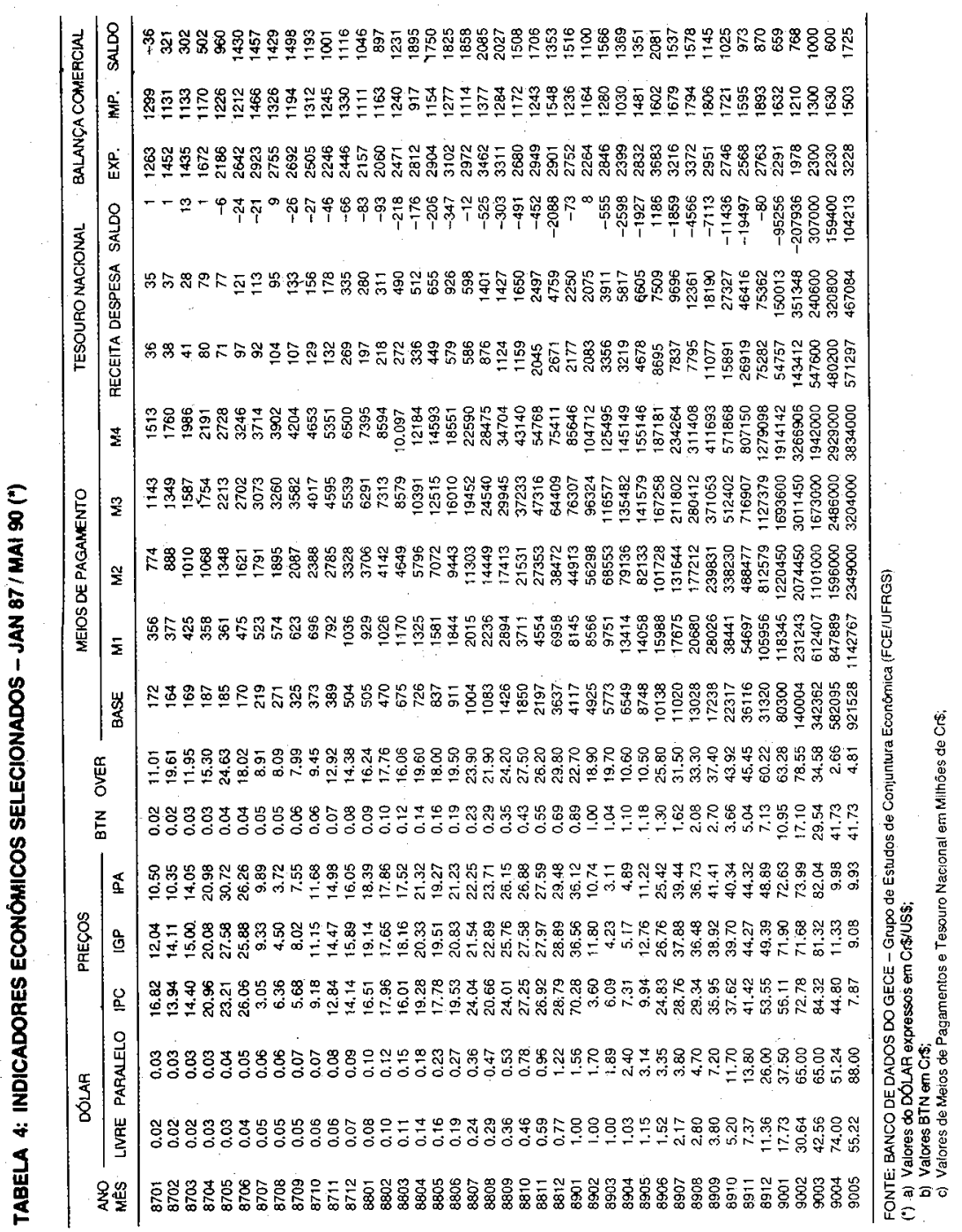




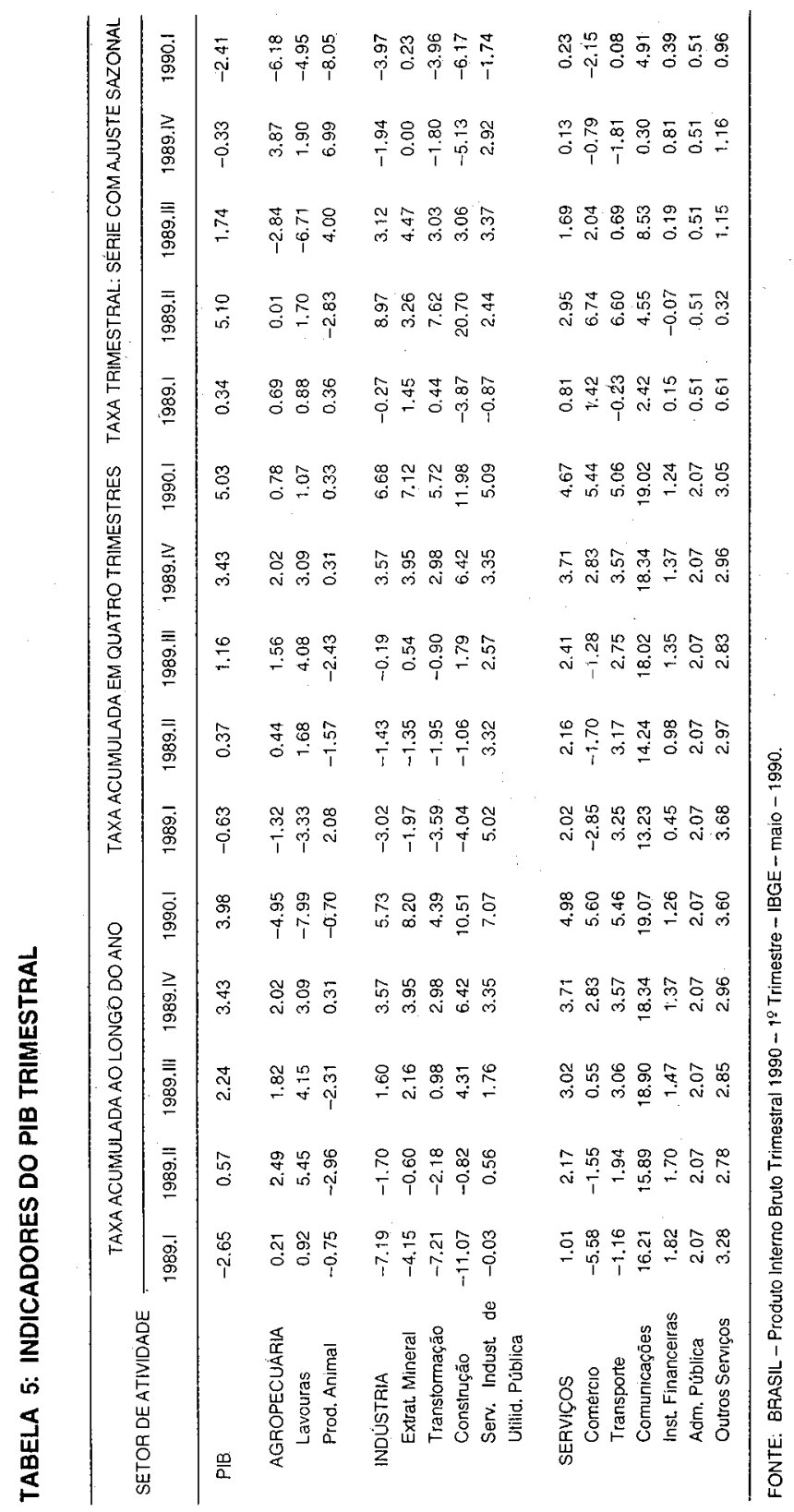


TABELA 6: M1/M4 E VARIAÇÃO PERCENTUAL DOS MEIOS DE PAGAMENTO - DEZ 88 / JUN 90

\begin{tabular}{|c|c|c|c|c|c|c|c|c|c|}
\hline \multirow{2}{*}{$\begin{array}{l}\text { ANOI } \\
\text { MÉS }\end{array}$} & \multirow{2}{*}{ M1/M4 (\%) } & \multicolumn{2}{|c|}{ M1 } & \multicolumn{2}{|c|}{ M2 } & \multicolumn{2}{|c|}{ M3 } & \multicolumn{2}{|c|}{ M4 } \\
\hline & & MÊS & ANO & MÊS & ANO & MÊS & ANO & MÊS & ANO \\
\hline 8812 & 9.2 & 50.5 & 570.3 & 40.7 & 1056.2 & 36.2 & 1063.1 & 37.7 & 1060.4 \\
\hline 8901 & & 17.3 & 17.3 & 17.6 & 17.6 & 20.8 & 20.8 & 15.6 & 15.6 \\
\hline 8902 & 8.5 & 5.2 & 23.4 & 25.2 & 47.2 & 24.2 & 50.1 & 20.5 & 39.3 \\
\hline 8903 & 7.8 & 13.8 & 40.4 & 21.1 & 78.2 & 20.7 & 81.1 & 19.5 & 66.5 \\
\hline 8904 & 10.0 & 37.6 & 93.2 & 17.2 & 108.9 & 17.2 & 112.2 & 16.6 & 94.2 \\
\hline 8905 & 9.0 & 4.6 & 102.1 & 2.2 & 113.4 & 3.6 & 119.8 & 6.0 & 105.7 \\
\hline 8906 & 8.5 & 13.9 & 130.2 & 23.8 & 164.1 & 18.1 & 159.6 & 20.6 & 148.0 \\
\hline 8907 & 7.5 & 10.6 & 154.5 & 29.4 & 241.9 & 26.6 & 228.8 & 25.2 & 210.6 \\
\hline 8908 & 6.6 & 17.0 & 197.8 & 34.5 & 359.9 & 32.3 & 335.0 & 32.8 & 312.6 \\
\hline 8909 & 6.8 & 35.5 & 303.6 & 35.4 & 522.9 & 32.4 & 475.8 & 32.3 & 445.8 \\
\hline 8910 & 6.7 & 37.2 & 453.6 & 40.9 & 777.8 & 38.0 & 694.8 & 38.4 & 655.2 \\
\hline 8911 & 6.6 & 42.3 & 687.7 & 44.3 & 1166.5 & 39.8 & 1011.1 & 41.8 & 971.0 \\
\hline 8912 & 7. & 92.8 & 1384.2 & 66.2 & 2004.6 & 58.2 & 1657.5 & 60.9 & 1623.7 \\
\hline 9001 & & 14.8 & 14.8 & 50.7 & 50.7 & 50.4 & 50.4 & 50.9 & 50.9 \\
\hline 9002 & 6.7 & 95.4 & 124.4 & 70.0 & 156.2 & 80.1 & 171.0 & 75.2 & 164.4 \\
\hline 9003 & 27.1 & 163.5 & 491.2 & -46.9 & 36.0 & -38.2 & 67.6 & -34.2 & 73.9 \\
\hline 9004 & 26.5 & 38.3 & 717.9 & 58.9 & 116.2 & 43.5 & 140.4 & 41.4 & 145.9 \\
\hline 9005 & 29.0 & 34.8 & 1008.8 & 34.6 & 190.9 & 20.5 & 189.7 & 23.2 & 202.8 \\
\hline
\end{tabular}

FONTE: Gazeta Mercantil (vários números) 


\section{RESUMO E ANDAMENTO DOS INSTRUMENTOS JURÍDICOS DAS REFORMAS: ADMINISTRATIVA (I), PATRIMONIAL (II), FISCAL (III), MONETÁRIA (IV), CAMBIAL (V), POLITICA DE PREÇOS E SALÁ- RIOS (VI) E OUTRAS (VII). ${ }^{1}$}

\section{A. MEDIDAS PROVISÓRIAS ${ }^{2}$}

\section{No 148, 15/03/90 (II)}

Dispõe sobre a alteração de Bens Imóveis da União situados em

Os dados foram coletados nos jornais Folha de São Paulo, Gazeta Mercantil, Diário Oficial da União e Serviço Prodazen. Trabalho elaborado pela bolsista Maristela Valerio Kopp (CNPq) com base nas fontes citadas.

o número entre parêntesis, abaixo de cada medida provisória listada, refere-se ao componente do Plano "Brasil Novo", conforme segue:

(l) Reforma Administrativa

A reforma Administrativa, incluindo toda a reestrutura do Estado com cortes de despesas, deverá resultar numa economia da ordem de $0,5 \%$ do PIB.

(ii) Reforma Patrimonial

A reforma patrimonial inclui o produto das vendas de empresas ou privatizaçâo de açóes, $e$ deverá resultar em mais de $2 \%$ do PIB, exceto a parcela que o governo pretende obter com a colocação compulsória de certificados de privatização (CPS) junto a instituiçōes financeiras em geral, que deverá render algo equivalente a $1,5 \%$ do PIB.

\section{(III) Reforma Fiscal}

As medidas tributárias incluem a redução dos prazos de recolhimento e indexação de tributos, ampliação da tributação ou aumento de alfquota e suspensão de todos os incentivos, incluindo os do Norte e Nordeste, com exceção daqueles que a constituição garante para a Zona Franca de Manaus. Somente essas medidas deverảo resultar num ganho orçamentário correspondente a $3 \%$ do PIB.

(IV) Reforma Monetária

A reforma monetária substitulu o cruzado novo por uma nova moeda - o cruzeiro - com validade desde 16/03/90 e regras especificas de conversão que amarram a polltica de controle rigoroso da liquidez na economia.

\section{(V) Reforma Cambial}

A taxa de câmbio oficial não será mais fixada arbritariamente, mas sim determinada pelo mercado formado por agentes já autorizados a operar com moeda estrangeira.

(VI) Políticas de Rendas e Salarial

A polftica de rendas e salários baseada na prefixação e desindexação da economia, será deteminada a partir de um "orçarnento de inflação" que será feito pelo ministério da economia, a partir do qual serão fixados os pisos salariais e tetos de preços que poderão variar automaticamente ao longo do mês.

(VII) Outras

Medidas complementares às reformas I até VI, buscando as condiçōes para a eficácia das referidas reformas. 
Brasília - DF, colocando a venda 43 mansões dos Ministros, objetivo: arrecadação de US\$58 milhōes, o valor deverá ser obrigatoriamente aplicado em programas habitacionais de caráter social.

Aprovada na integra, os recursos serão utilizados na construção de casas populares. Votada dia 03/04/90, Lei número 8011 (Diário Oficial 06/04/90)

\section{NN $149,15 / 03 / 90$ (II)}

Trata da venda de 10717 imóveis funcionais da União. As exceções são os destinados aos Militares, Diplomatas, Parlamentares, Ministros do Judiciário e os considerados "indispensáveis", o atual ocupante do imóvel poderá adquiri-lo, desde que pague o melhor preço apresentado em licitação da Caixa Econômica Federal, cada comprador pode adquirir apenas um imóvel e não poderá vendê-lo durante 5 anos.

Modificado pelo congresso no Projeto de Conversão número 19. As principais alterações prevêem que os atuais ocupantes terão preferência para a compra, ao preço definido pela Caixa Econômica Federal, sem entrar na licitação. $A$ compra pelos atuais ocupantes poderá ser feita em cruzados novos e não será permitida a quem possuir imóveis em Braslia. Foi sancionada sem veto. Foi votada dia 05/04/90. Lei 8025 (Diário Oficial dia 13/03/90).

\section{NN $150,15 / 03 / 90$ (I)}

Reforma administrativa. Reduz de 23 para 12 os Ministérios. Cancela dotações orçamentárias dos orgãos extintos (Cr\$ 494 bilhões), exceto as destinadas a pagamento de pessoal, e permite ao presidente redistribuir esses recursos sem autorização do congresso. Transfere a gestão do FGTS da Caixa Econômica Federal para o Ministério da Ação Social, extingue a CAPES e o INEP, ambos do Ministério da Educação.

Modificada pelo Congresso no Projeto de Conversão número 21. Modificaçōes: permite a transferência de dotação orçamentária dos órgãos extintos para aqueles que os substituirem, desde que mantida a natureza da despesa. Mantém a gestáo do FGTS na Caixa Econômica Federal (US\$ 7 bilhões). Recria a CAPES e o INEP, além do FAS (Função e Assessoramento Superior) dos órgãos que náo tiverem quadro proprio de pessoal. Cria o Fundo Nacional de Desenvolvimento e Cultura; o Conselho Nacional de Politica Cultural; $A$ criação do Fundo do Esporte Amador; o Conselho Administrativo de Defesa Econômica (CADE).

\section{NN $151,15 / 03 / 90(I, I)$}

Dispõe sobre a extinção e dissolução de entidades da administração pública federal. Extinção dos 25 seguintes órgãos: SUDECO, SUDESUL, DNOS, IAA, IBC, FUNARTE, FUNLACEN, FCB, FCP, PróMemória, Pró-Leitura, EDUCAR, PORTOBRAS, EBTU, EMBRATER, 
CAEEB, BNCC, INTERBRAS, PETROMISA, SIDERBRAS, EMBRAFILME, COBRAPI, INFAZ, Fundação Museu do Café. A operação atingirá 25 mil servidores, estando 10 mil deles sujeitos à demissão automática por não disporem de estabilidade. Economia de US\$1,8 bilhão.

Modificada pelo Congresso no Projeto de Conversão número 23. Foram mantidas a COBRAPI e a EMBRAFILME, a serem privatizadas em futuro proximo. Ficou preservada também a Fundação Palmares. O Banco do Brasil passa a incorporar o BNCC. O Congresso tentou garantir a indenização de dois meses de salário para os funcionários de nivel superior e de três para os de nivel médio. O governo calculou um dispêndio de US\$100 milhões com essas indenizaçóes. Foi sancionada com vetos. Votada dia 08/04/90. Lei 8029 (Diário Oficial 13/04/90). Vetos: Indenização para funcionários públicos demitidos; a transferência do BNCC para o Banco do Brasil; a passagem à EMBRAPA de funcionários extintos da PLANALSUCAR e os da Fazenda Experimental do Café; mantém a extinção da EMBRAFILME.

\section{№ $152,15 / 03 / 90(I$, VII)}

Reduz a transferência de recursos federais para órgãos de previdência privada.

Modificada pelo Congresso no Projeto de Conversão número 14. Texto aprovado com uma Emenda, que permite a cessão de funcionários de empresas públicas para essas entidades, desde que elas paguem seus salários. Foi sancionado sem veto. Votada dia 03/04/90. Lei 8020 (Diário Oficial 13/04/90).

\section{№ $153,15 / 03 / 90$ (VII)}

Define os crimes de abuso do poder econômico. (ver também Medida Provisória 175),

Retirada pelo Congresso por ser inconstitucional.

\section{No $154,15 / 03 / 90$ (VI)}

Institui nova sistemática para reajuste de preços e salários em geral (prefixação). Os preços ficam congelados até 30 de abril. No dia $1 \%$ de cada mês, o governo divulgará ó índice máximo de reajuste de preços. No dia 15, serão divulgados a meta inflacionária do mês e o indice mínimo de reajuste dos salários. Aumentos reais podem ser negociados livremente, sern repasse para o preço final do produto. $O$ salário-mínimo também será prefixado, mas, a cada trimestre, será concedido um aumento real de $5 \%$.

Modificada pelo Congresso no Projeto de Conversão número 28 mantida a prefixação. O indice de correção dos salários será sempre igual ou superior à meta inflacionária. Se o reajuste for inferior àiinflação efetiva do mês, a diferença 
será reposta a cada trimestre. Foram excluídos da prefixação os funcionários públicos estaduais e municipais. As empresas que concederem estabilidade a seus funcionários por 90 dias teráo acesso à linha de crédito no BC para financiar a folha de pagamento até 15 de julho. O salário-mínimo tem aumento real de $5 \%$ até julho $\theta$, depois, de $6,09 \%$ reais por trimestre. Foi sancionada com vetos. Votada dia 10/04/90. Lei 8031. (Diário Oficial 13/04/90). Vetos: crédito especial para folha de pagamento de empresas que derem estabilidade; a apresentação da polttica salarial ate 15/08/90; o gatilho destinado a cobrir eventuais perdas nos salários a cada três meses.

\section{N2 $155,15 / 03 / 90$ (I, II)}

Trata da privatização de empresas estatais. Cria o Programa Nacional de Desestatização. Permite a participação de capital estrangeiro na compra de estatais, abrindo a possibilidade para a fixação de um limite por razōes de interesse nacional. Proíbe a venda da PETROBRÁS e de empresas que exerçam atividades exclusivas da União, como Serviços Postais, de Telecomunicações e de Transmissão de Dados. Permite a conversão de débitos externos do país no processo de privatização.

Modificada pelo Congresso no Projeto de Conversáo número 27. Esse projeto inclui na lista das empresas não privatizáveis o Banco do Brasil, Instituiçóes Financeiras de caráter regional (como o Banco da Amazónia), o Instituto de Resseguro do Brasil e Empresas de Setores Estratégicos. Permite que o Congresso, através de Decreto Legislativo, suspenda a privatizaçáo de alguma estatal. Limita em $33 \%$ do capital volante e $49 \%$ do capital a participaçóes de capital estrangeiro em estatais privatizadas. Prolbe que Instituiçốes Financeiras Públicas financiem a venda de estatais. Determina que a utilização e a conversão de débitos externos ocorra apenas depois de regulamentada por lei a ser criada. Permite o uso de cruzado novos retidos no Banco Central. Foi sancionado com Vetos. Votada dia 10/04/90. Lei 8031 (Diário Oficial 13/04/90). Vetos: o poder de Veto do Congresso no processo de privatização; a avaliação das estatais pela CEF; a obrigaçáo de pagamento a vista das empresas a venda.

\section{N2 156, 15/03/90 (VII)}

Define crimes contra a Fazenda Pública, estabelecendo penalidades aplicáveis a contribuintes, servidores fazendários e terceiros que o pratiquem. (Ver também Medida Provisória 175).

Retirada do Congresso por ser inconstitucional.

\section{No $157,15 / 03 / 90(I, I I)$}

Cria o certificado de privatização, que terá de ser adquirido compulsoriamente por instituições financeiras, sociedades seguradoras e de 
previdência privada. Poderá ser usado na compra de ações de estatais.

Aprovada na integra. Votada dia 10/04/90. Lel 8018 (Diário Oficial 12/04/90). (Nota: no dia 15/05/90, através da resolução **** do Banco Central, foram regulamentados os certificados de privatização. Todas as instituiçóes financeiras autorizadas a funcionar pelo Banco Central terão de aplicar, no mínimo, $3 \%$ do ativo circulante e realizável a curto e longo prazo constantes no balanço patrimonial de 31/12/89. Esse valor não poderá superar $18 \%$ do património liquido da instituição).

\section{NN $158,15 / 03 / 90$ (l, III)}

Reduz o imposto sobre importações e extingue as Zonas de Processamento de Exportação (ZPE).

Modificada pelo Congresso no Projeto de Conversão número 16. A principal alteração introduzida inclui um artigo que suspende por 180 dias a implantação das Zonas de Processamento de Exportação (ZPE). Definiu-se, assim, que o executivo tem 90 dias para encaminhar ao Congresso uma proposta reformulando legislação das ZPE. Foi sancionado com Vetos. Votada 10/04/90. Lei 8032 (Diário Oficial 13/04/90). Vetos: Fundo Nacional da Marinha e a Isenção do Imposto de Importação.

\section{№ $159,15 / 03 / 90$ (I, VII)}

Cria um código de conduta do funcionalismo público. Proíbe a nomeação, para cargo de auxiliar direto, de parentes até segundo grau. Proíbe o comércio dentro das repartições públicas. Veta a acumulação de cargos públicos, a exceção dos permitidos pela constituição, como professor e médico. O servidor público não pode ser administrador de empresa que tenha negócios com o Éstado. Proíbe também a aceitação de propinas e presentes $e$, até mesmo, de empréstimos pessoais por funcionários públicos. Proibido "compelir" outro servidor a participar de partido político ou sindicato, bem como criticar de modo "depreciativo ou desrespeitoso" as autoridades ou atos do governo.

Modificada pelo Congresso no Projeto de Conversáo número 15. O texto original foi amenizado. Supridas as restrições à filiação sindical e partidária $\theta$ ao direito de critica. O projeto reune outras normas do Estatuto do Funcionalismo que náo eram citadas na Medida Provisória. Foi sancionada sem Veto. Votada dia 04/04/90. Lei 8027 (Diário Oficial 13/04/90).

\section{NN $160,15 / 03 / 90$ (III)}

Cria uma taxação especial do IOF (Imposto sobre Operações Financeiras). A tributação incidirá de uma só vez sobre os saldos das aplicações em 16 de março de 1990. Tributa em $8 \%$ de IOF as operações 
com títulos públicos e privados (overnight, fundos de curto prazo e CDBs); em $35 \%$, os ativos financeiros em ouro; em $25 \%$, as ações; e, em $20 \%$, os saques de caderneta de poupança. Isenta do IOF as cadernetas de poupança com saldos iguais ou inferiores a 10 mil BTNs fiscaiss. Concede uma redução das aliquotas para o contribuinte que recoIher o IOF devido até 16 de abril.

Modificada pelo Congresso no Projeto de Conversão número 30. Mantém as tributações. Isenta do IOF as cadernetás de poupança com saldo inferiores a 3,5 mil VRFs (Cr\$1,041 milhão). Foi sancionada com Vetos. Votada 06/04/90. Lei 8034 (Diário Oficial 13/04/90). A Medida Provisória 171 altera esta medida. Vetos: o artigo que garantia ao contribuinte o ressarciamento do imposto cobrado a mais entre 16 de março de 1990 e a promulgação da lei. (Nota: Em 15/05 o Banco Central assinou resolução 1706 ampliando a MP 168, que criou o $10 \mathrm{~F}$ de $20 \%$ sobre as transferências de titularidade. Foi anulada por ser considerada inconstitucional pelo Congresso).

\section{№ $161,15 / 03 / 90$ (III)}

Suspende, por tempo indeterminado, os incentivos fiscais destinados ao Nordeste e a Amazônia. Suspende também o incentivo para as empresas reinvestirem seus lucros. Ficam extintos os incentivos industriais, inclusive de informática. Lucros obtidos com exportação serão taxados em $30 \%$ do IR.

Modificada pelo Congresso no Projeto de Conversão número 20. Exime da extinção todos os subsidios de tarifas e preços expressamente criados por lei. $O$ corte de subsidios deverá ser reavaliado pelo Governo Federal em 30 de outubro deste ano. Excluído o corte de subsídios de energia elétrica que beneficiam as empresas produtoras de alumínio. Foi sancionado com Vetos. Votada dia 06/04/90. Lei 8034 (Diário Oficial 13/04/90). Vetos: o artigo que eliminará a concessão de quaisquer subsidios a tarifas públicas e que beneficiam usuários de serviços gerados por empresas controladas pela União.

\section{NN $162,15 / 03 / 90$ (III)}

Tributa os ganhos em Bolsas. Cria aliquota de $25 \%$ do Imposto de Renda para pessoa físicas e jurídicas que tiverem ganhos em Bolsas de Valores e de Mercadorias e em Mercados Futuros. A alíquota recairá sobre o Lucro Liquido em operações em Bolsas.

Aprovada na integra. Acaba com a isenção que existia há 20 anos. Votada dia 05/04/90.

\section{№ $163,15 / 03 / 90(I, V I I)$}

Estabelece a demissão e ação judicial contra funcionários da Re- 
ceita Federal que causarem prejuizos a União por ação ou omissão.

Modificada pelo Congresso no Projeto de Conversão número 11. Amplia para todo o universo de servidores a pena de demissão sumária para quem patrocinar por ação ou omissão prejulzos para a União. Foi sancionada sem Veto. Votada dia 03/04/90. Lei 8026 (Diário Oficial 13/04/90).

\section{NNo $164,15 / 03 / 90$ (III)}

Reduz prazos de pagamento de tributos de competência da União. "Betenização" dos Impostos. 06/04/90).

Aprovada na integra. Votada dia 03/04/90. Lei 8012 (Diário Oficial

\section{№ $165,15 / 03 / 90$ (VII)}

Indentificação dos contribuintes (fim do anonimato). Limita a emissão de cheques ao portador acima de 100 BTNs e proíbe os títulos ao portador.

Modificada pelo Congresso no Projeto de Conversão número 12. Texto aprovado com uma emenda, que retira o poder do Banco Central de alterar o limite de 100 BTNs. Foi sancionada sem Veto. Votada dia 03/04/90. Lei 8021 (Diário Oficial 13/04/90).

\section{№ 166, 15/03/90 (I, III)}

Transfere Receitas do INCRA para a Receita Federal, passa para a Receita a responsabilidade pelo recolhimento do ITR (Imposto Territorial Rural). A Receita ficará encarregada de elaborar o Sistema Nacional de Cadastro Rural, para facilitar a fiscalização do ITR.

Modificada pelo Congresso no Projeto de Conversão número 17. A única alteração feita permite que o INCRA continue com a responsabilidade de elaborar o Cadastro Rural. Foi sancionada sem Veto. Votada dia 05/04/90. Lei 8022 (Diário Oficial 13/04/90).

\section{№ $167,15 / 03 / 90$ (III)}

Altera a tributação do Imposto de Renda sobre a atividade rural. Os agricultores que são pessoas físicas e que tiverem lucro anual de até 11.800 BTNs pagam IR numa aliquota $10 \%$, depois de deduzir uma parcela de 6.840 BTNs. O lucro acima deste limite será tributado em $25 \%$ do IR. As empresas rurais pagarão $25 \%$ do IR. Os agricultores poderão reduzir em até $100 \%$ imposto a pagar, se mantiverem durante o anobase os recursos necessários ao seu próprio financiamento depositados num banco.

Modificada pelo Congresso no Projeto de Conversão número 22. A princi- 
pal alteração introduzida derruba a vinculação entre a arrecadação de impostos e a concessão de crédito. Foi sancionado sem Veto. Votada dia 06/04/90. Lei 8023 (Diário Oficial 13/04/90).

\section{№ $168,15 / 03 / 90$ (IV)}

Cria o cruzeiro e limita saques de contas e aplicações financeiras com base no saldo existente em 16 de março de 1990. Limita em Cr\$ 50 mil os saques nas contas correntes e na poupança; em $\mathrm{Cr} \$ 25 \mathrm{mil}$ ou $20 \%$ do saldo, os das aplicações no overnight e conta remunerada; e, em $20 \%$, os de aplicações compromissadas (como fundos de curto prazo). $O$ valor excedente fica bloqueado no $B C$ por 18 meses, sendo corrigido pelo BTN, mais juros de $6 \%$ ao ano. Será devolvido a partir de setembro de 1991, em 12 parcelas mensais sem correção.

Aprovada integralmente. Lei 8024 (Diário Oficial 13/04/90). Esta medida foi alterada pela Medida Provisória 172. (Nota: no dia 15/05/90 foi extinta a modalidade de aplicação em contas remuneradas, segundo resolução *** do Banco Central juntamente com outras medidas destinadas a reduzir o crédito).

\section{№ 169, 15/03/90 (IV)}

Autoriza leilões da dívida ativa da União.

Perdeu a validade por náo ter sido votada no prazo de 30 dias após a sua publicação. Foi reeditada no dia 18/04/90 com o número 178 (sem alteração).

\section{No 170, 17/03/90 (I, II)}

Proibe gastos com compra de carros oficiais.

Perdeu a validade por não ter sido votada no prazo de 30 dias após a sua publicação. Foi reeditada no dia 18/04/90 com número 179 (sem alteração).

№ $171,17 / 03 / 90$ (III)

Altera a Medida Provisória 160 (que trata do IOF. Modificações).

Aprovada juntamente com a medida 168. Votada dia 06/04/90. Lei 8033 (Diário Oficial 13/04/90).

\section{No $172,17 / 03 / 90$ (IV)} 180).

Altera a Medida Provisória 168. (Ver também Medida Provisória

Perdeu a validade por não ter sido votada no prazo de 30 dias após a sua publicação. Foi reeditada no dia 18/04/90 com o número 180.

\section{N2 $173,18 / 03 / 90$ (VII)}

Proíbe liminares contra as medidas do Plano. Não será concedida 
medida liminar em mandatos de segurança e em ações ordinárias e cautelares decorrentes das MP 151, 154, 158, 160, 161, 162, 164, 165, 167 e 168, aplicando-se o disposto no parágrafo único do artigo 5 da Lei 4348 de 26/06/64.

Perdeu a validade por não ter sido votada no prazo de 30 dias após a sua publicação. Foi reeditada no dia 18/04/90 com número 181.

\section{№ $174,23 / 03 / 90$ (IV)}

Modifica os artigos 11, 1213 e 18 da Medida Provisória 168, de 15/03/90. (Ver também MP 180).

Perdeu a validade por não ter sido votada no prazo de até 30 dias após a sua publicação. Foi reeditada no dia 18/04/90 com o número 180.

\section{№ $175,27 / 03 / 90$ (VII)}

Revoga as Medidas 153 e 156. Regula a prisão e o pagamento de fiança nos casos em que se verifica crime contra a economia popular e de sonegação fiscal. O valor mínimo da fiança passa a ser de 10 mil e o máximo de 100 mil BTNs na data do crime (BTNs Fiscais). O juiz pode reduzir o valor em até $67 \%$ ou aumentá-lo dez vezes.

Foi modificada pelo Congresso. Foi aprovado o Projeto de Lei de Conversão, que alterou, o limite de redução do valor da fiança. O juiz pode agora reduzir a fiança em até $90 \%$, em vez de $67 \%$. Votada dia 26/04/90. Sancionada. Lei 8035.

\section{No 176, 29/03/90 (VI)}

Fixa critérios para reajustes de mensalidades escolares. (Ver Medida Provisória 183).

Perdeu a validade por não ter sido votada no período de trinta dias. Foi reeditada pela Medida 183.

\section{No $177,12 / 04 / 90$ (I)}

Transfere a gestão do FGTS para o Ministério da Ação Social. A Caixa Econômica Federal (CEF) fica como agente operador do fundo. $O$ recolhimento e a aplicação do FGTS continua sendo supervisionados por um Conselho Curador formado por representantes dos trabalhadores, empresários e governo.

O projeto de Conversão manteve o Ministério da Ação Social como gestor do FGTS e a CEF, como operador, mas restabelece a importância do Conselho Curador, que havia sido esvaziado pela Medida Provisória. O Conselho vai estabelecer as diretrizes para aplicação dos recursos do Fundo. Votada pelo Congresso dia 09/05/90. 


\section{№ 178, 17/04/90 (IV)}

Autoriza leilões da Divida Ativa da União.

Reedita Medida a Medida Provisória 169. Perdeu a validade por não ter sido votada no prazo de 30 dias após a sua publicação.

№ 179, 17/04/90 (I,II)

Proíbe gastos com a compra de carros oficiais.

Reedita Medida Provisória 170. Perdeu a validade por não ter sido votada no prazo de 30 dias após a sua publicação.

\section{№ $180,17 / 04 / 90$ (IV)}

É a reedição das Medidas 172 e 174 fundidas. Estas últimas, modificaram a Medida 168 , transformada na Lei 8024 . Proibe a Ministra da Economia de aumentar o prazo de 18 meses para início da devolução dos cruzados novos bloqueados. Fica apenas autorizado a redução do prazo ou elevação dos limites dos saques das aplicações financeiras. Autoriza a Ministra a realizar antecipadamente leilões de cruzados novos para a liberação de cruzeiros com o objetivo de política monetária. Permite o pagamento de impostos, taxas e contribuiçōes previdenciárias em cruzados novos até 18 de maio deste ano. Determina que a caderneta de poupança passará a ser reajustada a partir de maio pela variação da BTN. Dívidas contraidas antes de 15 de março e com vencimento até 100 dias após a edição do Plano Collor podem ser pagas em cruzados novos, a critério do devedor.

Foi revogada pelo Governo. Com a revogação, a Ministra da Economia Zélia C. de Mello voltou a ter poderes para ampliar o períndo de retenção dos depósitos nas cadernetas de poupança e demais ativos financeiros além dos 18 meses previstos. Ver medida 184.

\section{NN $181,17 / 04 / 90$ (VII)}

É a reedição da Medida Provisória 173.

Suspensa pela Medida Provisória 182.

\section{No $182,23 / 04 / 90$ (VII)}

Proibe liminares contra as Medidas do Plano Brasil Novo pelo pra$z 0$ de 30 meses, a contar de 15/03/90. Suspende a medida 181. Proíbe liminares contra Medidas do Plano (contidas nas Leis 8012, 8014, 8021, 8023, 8024, 8029, 8030, 8032, 8033, e 8034, e nas Medidas Provisórias $176,178,179$ e 180).

Perdeu a validade por não ter sido votada no prazo de 30 dias após a sua 
publicação. Reeditada pela terceira vez, agora pela Medida Provisória 186.

\section{№ $183,30 / 04 / 90(\mathrm{VI})$}

Fixa critérios para reajustes de mensalidades escolares.

Aprovada pelo Congresso no dia 29/05/90. Apenas o artigo 5 foi suprimido.

\section{№ $184,07 / 05 / 90$ (IV)}

Revoga a Medida Provisória 180, que alterava a Medida Provisória 168 , que implantou a reforma monetária e limitou saques em conta corrente, cadernetas de poupança e aplicações financeiras. Nesta Medida, desaparece a limitação dos poderes da Ministra da Economia quanto a ampliação ou redução do prazo de retenção dos depósitos em cruzados novos bloqueados no Banco Central.

(Nota: a medida tenta evitar a rediscussão, no Congresso Nacional, dos limites de saque.). Perdeu a validade por não ter sido votada no prazo de trinta dias após a sua publicação. Não foi reeditada pelo governo.

\section{NN 185, 07/05/90 (VII)}

Dá ao Tribunal Superior do Trabalho (TST) o poder de suspender os dissídios coletivos.

O Congresso rejeitou no dia 31/05 esta Medida. Foi a primeira medida do Plano Brasil Novo derrubada pelo Congresso. No mesmo dia o governo reeditou uma nova Medida Provisória, com o número 190, que mantém o efeito suspensivo dos dissídios coletivos. Substituída pela MP número 190.

\section{No $186,25 / 05 / 90$ (VII)}

Estabelece as hipóteses nas quais fica suspensa a concessão de medidas liminares.

Perdeu a validade por não ter sido votada no prazo de trinta dias após a sua publicação. Foi reeditada pelo governo através da Medida Provisória de número 192.

\section{№ $187,30 / 05 / 90$ (I)}

Dispõe sobre a competência das autoridades que menciona. As competências previstas na legislação comum e na especial, atribuídas aos titulares dos cargos extintos por força do disposto no Art. 25 da Lei 8028 de 12/04/90, consideram-se desde logo, transferidas aos titulares, dos órgãos a que alude o Artigo 1, Parágrafo Único, Alinea " $\mathrm{C}$ ", bem assim aos ocupantes dos cargos referidos nos Art. 24 e 26, inciso I a IV, da mesma Lei 8028. 
N9 188, 30/05/90 (1)

Prorroga até o dia 31/12/90, a vigência dos dispostos legais quı hajam atribuido ou delegado ao Conselho Monetário Nacional, e ac Consellho Nacional de Seguros Privados, competências assinaladas pela Constituição, ao Congresso Nacional. A Medida definiu também : nova estrutura administrativa do Conselho, que teve o número de seu: membros reduzidos de 24 para 11.

\section{N2 189, 31/05/90 (IV)}

Esta Medida isenta do IR os juros da poupança que superam o I: mite de isenção da tabela do Imposto de Renda. Foi criado também . Índice de Reajuste de Valores Fiscais (IRVF) que tem o objetivo de da credibilidade ao Bônus do Tesouro Nacional (BTN). O IRVF será calcu lado entre a quarta semana de um mês e as três primeiras semanas do més seguinte.

\section{N2 190, 01/06/90 (VII)}

Reedita com alterações, a Medida Provisória 185 (rejeitada no dí 01/06 pelo Congresso Nacional). Amplia em quase dois meses a com petência do Tribunal Superior do Trabalho (TST) para suspender a con cessão de reajustes salariais determinados pelos Tribunais Regionai: do Trabalho (TRTs). O TST tem até 27 de novembro para suspender : execução das decisões dos TRTs, e a duração da suspensão é indefini da, já que não há prazo para o julgamento final dos dissídios. Esta me dida inova ao permitir que os sindicatos representem suas categorias ni justiça sem autorização por escrito.

Esta medida teve a sua tramitação interrompida pela Liminar concedid: pelo STF na ação direta de inconstitucionalidade. Foi revogada pela Medida Pro visória 193.

\section{N2 191, 06/06/90 (VII)}

Dispõe sobre o reajuste das prestações pactuadas nos contrato: de financiamento firmado no âmbito do Sistema Financeiro de Habita ção, vinculado ao Plano de Equivalência Salarial. Ela prevê que os rea justes serão feitos pela variação do BTN, a partir de março, ou pelo ín dice de reajuste salarial, o que for menor, para os contratos com equi valência salarial parcial. $A$ medida trata apenas dos contratos vinculado: aos aumentos de salários. Contratos que são reajustados por outros ín dices permanecem inalterados. 
№ 192, 25/06/90 (VII)

Estabelece hipóteses nas quais fica suspensa a concessão de Medidas Liminares contra o Plano Collor, reedição da MP 186.

\section{№ $193,25 / 06 / 90$ (VII)}

Dispõe sobre a garantia de salário efetivo. Os reajustes salariais definidos em acordos coletivos poderão ocorrer apenas duas vezes a cada 12 meses. Fixa um reajuste mínimo com base na média dos 12 meses entre as datas-base do trabalhador. Os aumentos salariais decorrentes da Medida Provisória não podem ser repassados aos preços. Caso a proibição não seja respeitada, o infrator estará sujeito à aplicação da Lei Delegada número 4, que prevê punições como o fechamento de estabelecimentos, multas e interdições temporárias. Para calcular o "salário efetivo", o governo criou o Fator de Recomposição Salarial (FRS). Ele será corrigido pela variação diária do IPC do mês seguinte. Os critérios não valem para o funcionalismo público civil e militar, aposentados e pensionistas da previdência privada. (ATENÇÄO: o texto revoga a Medida Provisória 190).

\section{B. DECRETOS}

\section{NN 99.177, 15/03/90 (l)}

Dispõe sobre o regime de acumulação de cargos e empregos. Os órgãos de administração pública federal direta, as autarquias, as fundações e empresas públicas e as sociedades de economia mista são obrigadas a fornecer informações sobre o seu pessoal na forma estabelecida pela Secretaria de Administração Federal, da Presidência da República.

\section{N2 $99.178,15 / 03 / 90$ (I)}

Dispõe sobre a contenção de despesas na administração públịca federal. Os veículos automotores de transporte rodoviário da administração pública federal direta, das autarquias e das fundações públicas que forem considerados não essenciais serão leiloados no prazo de 60 dias a contar da publicação deste decreto; cria-se critérios para liberar viagens ao exterior pagas pelo Governo Federal, a contratação de serviços de publicidade dos Órgãos da Presidência da República e dos Ministérios será efetuada por intermédio da Comissão Exclusiva de Licitação de Preços de Publicidade. E dá outras providências. 


\section{№ $99.179,15 / 03 / 90$ (I, VII)}

Institui o programa federal de desregulamentação, com a finalidade de fortalecer a iniciativa privada, reduzir a interferência do Estado na vida e nas atividades do indivíduo, contribuir para a maior eficiência e o menor custo dos serviços prestados pela administração pública federal direta e sejam satisfatoriamente atendidos os usuários destes serviços. A atividade econômica privada seră regida, basicamente, pelas regras do livre mercado, limitada a interferência da administração pública federal ao que dispõe a constituição. Serão adotadas as medidas necessárias para a extinção dos órgãos de entidades públicas cujas atribuições se tornem supérfluas. Será criada uma comissão especial presidida pelo Secretário-Geral da Presidência da República.

\section{№ $99.180,15 / 03 / 90$ (l)}

Dispõe sobre a reorganização e o funcionamento dos órgãos da Presidência da República e dos Ministérios. A administração pública federal passa a ter 12 Ministérios, Secretária-Geral da República, Gabinete Militar, Gabinete Pessoal da Presidência da República, Conselho dá República, Conselho da Defesa Nacional, Conselho do Governo, Alto Comando das Forças Armadas, Consultoria Geral da República, e mais 7 Secretarias.

Dispõe sobre a competência e estrutura dos órgãos.

\section{NN $99.181,15 / 03 / 90$ (III)}

Dispõe sobre a legislação do Imposto sobre Produtos Industrializados. A partir do dia 19/03/90, os produtos sujeitos ao regime tributário de que trata o Artigo 1 da Lei 7798, de 10 de julho de 1989, estarão sejeitos, por unidade, ao Imposto sobre Produtos Industrializados - IPI fixado em Bônus do Tesouro Nacional - BTN. Os valores do Imposto de que trata este Decreto serão reajustados: a)Mensalmente, nos mesmos índices do Bốnus do Tesouro Nacional; b)Tratando-se de produtos de preços controlados por órgão do poder Executivo, na data do início de vigência do preço de venda reajustado e nos mesmos indices.

\subsection{2, 15/03/90 (III)}

Dispõe sobre a legislação do Imposto sobre Produtos Industrializados. Ficam alteradas as alíquotas de Imposto sobre Produtos Industrializados relativas às mercadorias indicadas no anexo do Diário Oficial de 16/03/90 página 5548. 
№ 99.183, 15/03/90 (I)

Dispõe sobre a legislação relativa à contenção de despesas na administração pública federal.

\section{NN $99.184,15 / 03 / 90$ (I, II)}

Regulamenta o Cadastro Nacional de Bens Imóveis. O Departamento do Patrimônio da União - DPU - ampliará o seu Cadastro de Bens Imóveis, transformando-o em Cadastro Nacional dos Bens Imóveis, do qual constarão todos os elementos necessários à sua identificação. Os órgãos de administração direta, INCRA, INSS, FUNAl e demais órgãos de administração indireta, empresas públicas controladas pela União, autarquias e fundações mantidas pelo poder público enviarão ao Departamento do Patrimônio da União, no prazo máximo de trinta dias, a contar da data de publicação deste decreto, a relação dos bens que thes pertencem ou que thes são jurisdicionados, acompanhada do Documento de Cadastro - DC de cada imóvel. Estas entidades fornecerão, mensalmente, ao DPU, a atualização dos dados fornecidos.

\section{NN 99.186, 17/03/90 (I, II)}

Dispõe sobre procedimentos relativos aos servidores em exercícios nos órgãos e entidades extintos ou dissolvidos da administração pública federal. Os servidores dos ministérios, autarquias e fundações extintos, nos termos das Medidas Provisórias 150 e 151, de 15/03/90, deverão apresentar-se nas dependências dos órgãos de pessoal dos ministérios ou entidades em que estavam em exercício, a fim de atualizarem seus dados cadastrais.

\section{№ $99.187,17 / 03 / 90$ (I)}

Delega competência ao chefe do Estado-Maior das Forças Armadas, aos titulares das Secretarias da Presidência da República e ao Consultor-Geral da República para praticar atos de provimento ou de designação, nas respectivas áreas de competência.

1 - cargos e funções de confiança dos niveis $1,2,3$, e 4, do grupo de Direção e Assessoramento Superior (DAS), (DAl);

II - de funções do Grupo de Direção e Assistência Intermediárias

III - de funções ou gratificações de tabelas especiais especificas; 
NN 99.188, 15/03/90 (I, II) deral.

Dispõe sobre contenção de despesas na administração pública fe-

No 99.192, 20/03/90 (IV)

Dispõe sobre a extinção e dissolução de Entidades da Administração Pública Federal. Ficam dissolvidas as seguintes entidades: 1 PORTOBRÁS; II - CAEEB; III - BNCC; IV - INTERBRÁS; V - PETROMISA; VI - SIDERBRÁS; VII - EMBRAFILME; VIII - COBRAPI; IX - INFAZ; X - EBTU; XI - EMBRATER.

\section{PROJETO DE LEI}

PL (15/03/90)

O Projeto de Lei institui o imposto sobre grandes fortunas e dá outras providências.

CLASSE DE VALOR DO PATRIMÔNIO

(EM BTN)

ALÍQUOTA

Até 1.000 .000

Mais de 1.000 .000 até 3.000 .000

Isento

Mais de 3.000 .000 até 5.000 .000

$0,1 \%$

Mais de 5.000.000 até 10.000.000

$0,2 \%$

Mais de 10.000 .000

$0,4 \%$

$0,7 \%$

\section{BIBLIOGRAFIA}

BOLETIM DE CONJUNTURA. IEI/UFRJ, Rio de Janeiro, v. 10, n 1, abr. 1990.

BRASIL, PROGRAMA ECONÔMICO. BACEN, Brasilia, v. 17, jun. 1988. 
BACEN, Brasilia, v. 22, set. 1989.

CRUSIUS, Yeda R. O Plano "Brasil Novo" como uma proposta de Mudança de Regime. Indicadores Econômicos FEE, Porto Alegre, v. 18, n. 1, p. 13 - 18, abr. 1990.

FARO, C. de (org.): Plano Collor: Análise e Perspectivas. Rio de Janeiro, Livros Técnicos e Científicos, 1990.

GECE - Grupo de Estudos de Conjuntura Econômica. Porto Alegre, FCE/UFRGS, Jan.-dez. 1989. (Fatos relevantes).

GURLEY, J. G. O Excesso de Liquidez e Reformas Monetárias Européias, 1944-1952. Ensaios FEE, Porto Alegre, v. 11, $n^{0}$ 1, p. 223-249, 1990.

PASTORE, Afonso C.: A Reforma Monetária do Plano Collor. São Paulo, 1990. (Mimeo).

PLANO DE CONTROLE MACROECONÔMICO. MINFAZ, Brasília, jul. 1987. 